\title{
Impaired macrophages and failure of steroidogenesis and spermatogenesis in rat testes with cytokines deficiency induced by diacerein
}

\author{
Salmo Azambuja de Oliveira ${ }^{1} \cdot$ Paulo Sérgio Cerri ${ }^{2} \cdot$ Estela Sasso-Cerri $^{2}$ (i) \\ Accepted: 8 August 2021 / Published online: 13 September 2021 \\ (c) The Author(s), under exclusive licence to Springer-Verlag GmbH Germany, part of Springer Nature 2021
}

\begin{abstract}
The role of cytokines in testicular function under normal conditions has not been completely understood. Here, we evaluated testicular macrophages (TM), steroidogenesis by Leydig cells (LC) and seminiferous tubules integrity in cytokines-deficient rat testes induced by diacerein, an anti-inflammatory drug that inhibits interleukin-1 (IL-1) and tumor necrosis factor-alpha (TNF- $\alpha$ ). Male rats received daily $100 \mathrm{mg} / \mathrm{kg}$ of diacerein (DIAG; $n=8$ ) or saline (CG; $n=8$ ) for 30 days. Serum testosterone (T) levels were measured and the seminiferous tubule (ST) area, epithelial area (EA), frequency of damaged ST and number of Sertoli cells (SC) were evaluated. TUNEL method and immunoreactions for detection of pro-IL- $1 \beta$, TNF- $\alpha$, steroidogenic acute regulatory protein (StAR), 17 $\beta$-hydroxysteroid dehydrogenase (17 $\beta$-HSD), androgen receptor (AR) and scavenger receptor for hemoglobin-haptoglobin complexes (CD163), a TM marker, were performed. Testicular AR, 17 $\beta$-HSD and IL-1 $\beta$ levels were detected by Western blot. Data were submitted to Student t test $(p \leq 0.05)$. In DIAG, T and testicular AR, 17 $\beta$-HSD and IL-1 $\beta$ levels decreased significantly $(p<0.05)$. The number of TUNEL-positive interstitial cells increased and LC showed weak StAR, 17 $\beta$-HSD and AR immunoexpression in association with reduced IL-1 $\beta$ immunoexpression and number of CD163positive TM in the interstitial tissue from diacerein-treated rats. Numerous damaged ST were found in DIAG, and reduction in the EA were associated with germ cells death. Moreover, the number of SC reduced and weak AR and TNF- $\alpha$ immunoexpression was observed in SC and germ cells, respectively. The cytokines deficiency induced by diacerein impairs TM, LC and spermatogenesis, and points to a role of IL- $1 \beta$ in steroidogenesis under normal conditions. In the ST, the weak AR and TNF- $\alpha$ immunoexpression in SC and germ cells, respectively, reinforces the idea that TNF- $\alpha$ plays a role in the SC androgenic control.
\end{abstract}

Keywords Anti-inflammatory $\cdot \mathrm{IL}-1 \cdot \mathrm{TNF}-\alpha \cdot$ Spermatogenesis $\cdot$ Leydig cell $\cdot$ Macrophage

\section{Introduction}

In vitro and in vivo studies have demonstrated some mechanisms involved in the interaction between Leydig cells (LC) and testicular macrophages (TM) (Bornstein et al. 2004; Loveland et al. 2017). In testes, there are two populations of resident macrophages; one of them (ED1 macrophage)

Estela Sasso-Cerri

estela.sasso@unesp.br

1 Department of Morphology and Genetics, Federal University of São Paulo, São Paulo, Brazil

2 Laboratory of Histology and Embryology, Department of Morphology, Genetics, Orthodontics and Pediatric Dentistry, Dental School - São Paulo State University (UNESP), Rua Humaitá, 1680, Araraquara, SP CEP: 14801-903, Brazil is a type of recently recruited or transient macrophage that expresses the lysosomal antigen CD68 (Hedger 1997), and is found surrounding the peritubular tissue next to the spermatogonial stem cells (de Falco et al. 2015). The other population of TM, also named ED2 macrophages (Hedger 1997), are located in the interstitial tissue in close contact with LC (Mossadegh-Keller et al. 2017) and expresses scavenger receptors CD163 involved in endocytosis of hemoglobinhaptoglobin complexes, being responsible for iron recycling (Van Gorp et al. 2010. It is known that TM are the main immune cell in the adult rodent normal testis (Winnall and Hedger 2013; Indumathy et al. 2020) and play essential role during inflammatory responses (Meinhardt et al. 2018). Moreover, under physiological conditions, the macrophages in close contact with LC seem to provide an ideal niche that maintain LC functions, including steroidogenesis (Nes et al. 2000; Hutson 2006; Smith et al. 2015; Loveland et al. 2017). 
ED2 macrophages allow the direct transport of specific molecules to LC, such as 25-hydroxycholesterol and 25-hydroxylase (Lukyanenko et al. 2001) (Fig. 1). Cholesterol is essential for steroidogenesis, whose initial step depends on the steroid acute regulatory protein - StAR responsible for the mobilization of cholesterol to mitochondria and production of pregnenolone which, after several enzymatic processes in the smooth endoplasmic reticulum, is converted into androstenedione and finally into testosterone by $17 \beta$-HSD (Beattie et al. 2015) (Fig. 1).
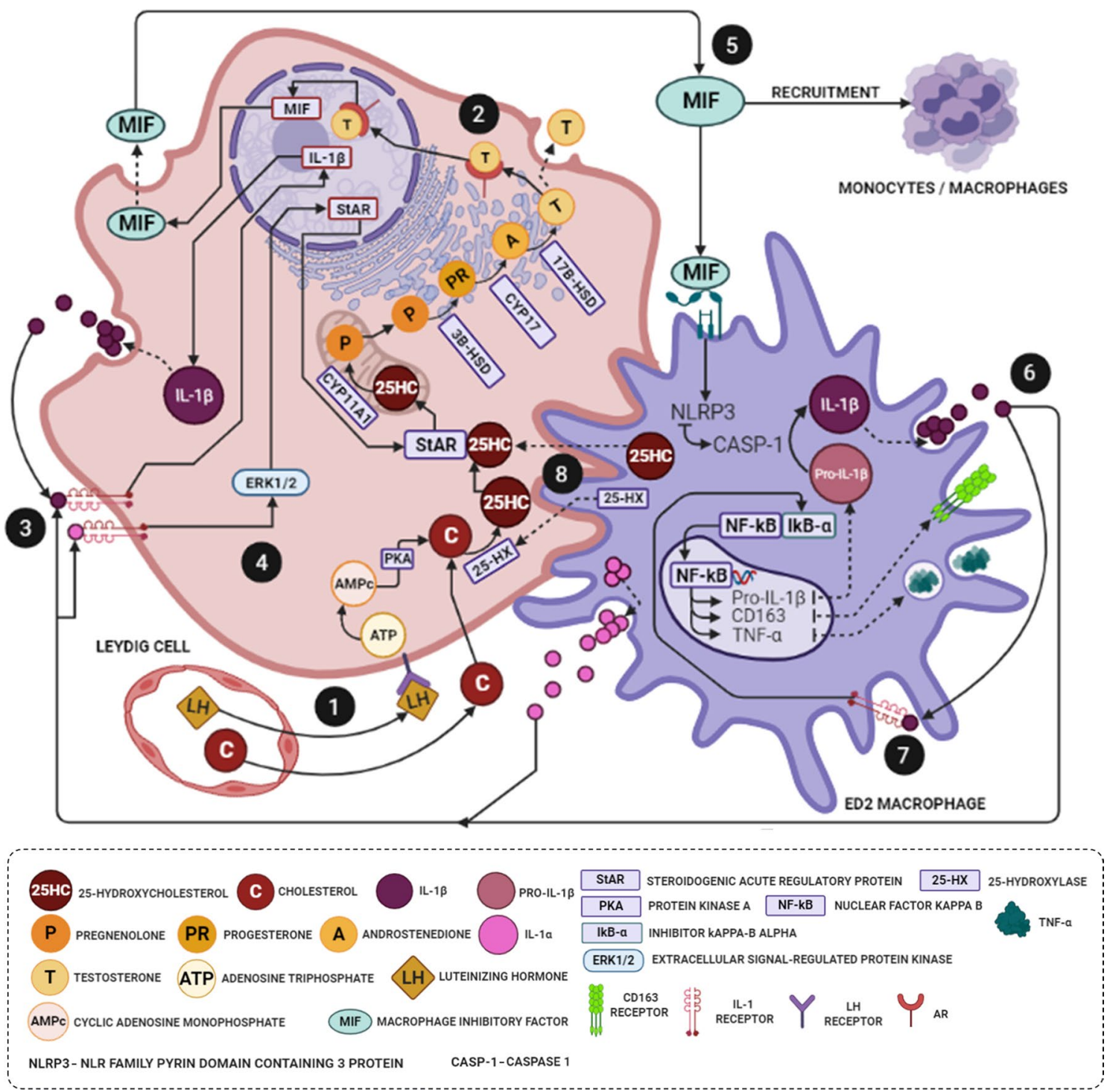

Fig. 1 Leydig cell (LC) steroidogenesis and ED2 testicular macrophage (TM) showing cytokines synthesis, and LC-TM paracrine interaction under normal condition. 1-) LH activates cAMP-dependent protein kinase A, which mobilizes and transports cholesterol $(\mathbf{C})$, derived from the blood stream. $\mathrm{C}$ is converted into 25 -hydroxycholesterol $(25-\mathrm{HC})$ by 25 -hydroxylase (25-HX). StAR transports $25-\mathrm{HC}$ to mitochondria where is metabolized into pregnenolone $(\mathrm{P})$ by CYP11A1 enzyme. In smooth endoplasmic reticulum, $\mathrm{P}$ is metabolized into progesterone (PR) by $3 \beta-\mathrm{HSD}$, and into androstenedione (A) by CYP17. Finally, A is converted into testosterone (T) by $17 \beta-$ HSD, and T is released to the extracellular milieu. 2-) Via autocrine, $\mathrm{T}$ binds to androgen receptor (AR) in LC and is translocated to the nucleus, activating AR responsive genes, such as MIF, which is secreted and released by LC. 3-) LC expresses IL-1 receptor (IL-1R);
IL-1 $\beta /$ IL-1R binding stimulates IL-1 $\beta$ secretion via autocrine signaling. 4-) IL- $1 \alpha / \beta$ bound to IL-1R also stimulates StAR expression through ERK1/2 pathway, triggering the activation of StAR binding to 25-HC and subsequent steroidogenesis. 5-) The LC-produced MIF stimulates the recruitment of new monocytes/macrophages or is internalized by TM via CD74 receptor, stimulating NLRP3 complex and subsequent capase-1 (CASP-1), which converts Pro-IL-1 $\beta$ into active IL-1 $1 \beta$. 6-) IL- $1 \beta$ released by LC binds to IL-1R in TM (autocrine signaling) and/or to IL-1R in LC (paracrine signaling). 7-) In TM, IL-1 $\beta$ triggers IkB- $\alpha$ degradation and activates NF-kB translocation to nucleus. NF-kB triggers genes expression, such as pro-IL-1 $\beta$, CD163 and TNF- $\alpha$. 8-) TM also transport 25-HC and/or 25-HX directly to LC, contributing to the steroidogenic activity of LC. Created using BioRender.com 
Studies have demonstrated that cytokines participate in development, function and maintenance of testes under normal conditions (Verhoeven et al. 1988; Warren et al. 1990; Meinhardt et al. 1996; Svechnikov et al. 2003). Although the exact role of cytokines in adult testes has not been completely understood, some cytokines such as interleukin-1 (IL-1) (Verhoeven et al. 1988; Warren et al. 1990; Cudicini et al. 1997; Gerendai et al. 2005), IL-6 (Syed et al. 1995; Cudicini et al. 1997), tumor necrosis factor (TNF- $\alpha$ ) (Warren et al. 1990; De et al. 1993) and macrophage migration inhibitory factor (MIF) (Meinhardt et al. 1996) seem to mediate some functions of LC, macrophages, Sertoli cells (SC) and germ cells. Either ED1 (CD68) or ED2 (CD163) macrophages produce several cytokines (Hedger 2002), which act via paracrine and/or autocrine signaling, regulating cell-cell interaction (Bornstein et al. 2004). Testicular macrophages produce either IL- $1 \alpha$ (Söder et al. 2000) or IL-1 $\beta$ (O'Bryan and Hedger 2008). IL-1 exerts an autocrine action on macrophages (Dinarello 1987) (Fig. 1). The binding of IL-1 to IL-1 receptor (IL-1R) activates IL-1R-associated kinase (Voronov et al. 2013) and triggers the activation of IkB- $\alpha / \mathrm{NF}-\mathrm{kB}$ complex, inducing degradation of IkB- $\alpha$ (Haseeb et al. 2013). Thus, the free NF-kB is translocated to nucleus and activates the expression of several genes, including pro-IL-1 $\beta$ (O'Bryan and Hedger 2008), TNF- $\alpha$ (O'Bryan and Hedger 2008; Dorrington and Fraser 2019) and CD163 (Fujiwara et al. 2010) (Fig. 1).

Studies have demonstrated that LC also expresses either IL-1R (Svechnikov et al. 2001) or IL-1mRNA under normal conditions (Verhoeven et al. 1988; Warren et al. 1990; Lin et al. 1993; Cudicini et al. 1997) (Fig. 1). Although the role of this interleukin in LC under normal conditions is not completely understood, studies have demonstrated that either IL-1 $\alpha$ (Manna et al. 2007) or IL-1 $\beta$ (Verhoeven et al. 1988; Warren et al. 1990) stimulates steroidogenesis in LC (Fig. 1). According to Manna et al. (2007), IL1- $\alpha$ stimulates the transcription of STAR gene, via ERK 1/2, and subsequent StAR synthesis in LC (Fig. 1). In culture of human granulosa-lutein cells, IL1- $\beta$ upregulates StAR expression and stimulates steroidogenesis, which is inhibited by IL-1 receptor antagonist (Dang et al. 2017). LC also synthesizes MIF, a cytokine involved in the monocyte/macrophage recruitment (Hedger 2002). This factor binds to CD74 receptor in TM and triggers the activation of the multi-protein complex NLRP3 and caspase-1 (interleukin-1 $\beta$ converting enzyme), which converts Pro-IL-1 $\beta$ into active IL-1 $\beta$ (Shin et al. 2019) (Fig. 1). Therefore, the LC-TM coupling is essential for testicular function, including steroidogenesis, and cytokines seem to mediate this process.

Although there are few studies on the role of cytokines in the seminiferous epithelium under normal conditions, studies by Gérard et al. (1991) and Cudicini et al. (1997) have demonstrated IL-1 $\alpha$ mRNA expression in SC, which seem to be the main secretory cell of IL-1 $\alpha$ in the testis. Moreover, germ cells, such as pachytene spermatocytes and round spermatids also synthesize TNF- $\alpha$ (De et al. 1993; Suominen et al. 2004). This factor seems to maintain spermatogenesis by inhibiting germ cell apoptosis via FasL (CD95L) downregulation (Pentikäinen et al. 2001). Moreover, a study by Delfino et al. (2003) has demonstrated that TNF- $\alpha$ induces the expression of androgen receptor (AR) in SC culture and, in TNF- $\alpha$ knockout mice, either steroidogenesis or spermatogenesis is impaired, and the concentration of sperm is reduced in comparison with wild-type mice (Suh et al. 2008). Therefore, these findings reinforce the idea that TNF- $\alpha$ is essential for the maintenance of testicular androgenic function and spermatogenesis under normal conditions.

Diacerein is an anti-inflammatory agent clinically prescribed for the treatment of osteoarthritis (Martel-Pelletier and Pelletier 2010; Pavelka et al. 2016), liver steatosis and fibrosis induced by type 2 diabetes mellitus (Leite et al. 2019) as well as obese or overweight patients with diabetes mellitus (Ramos-Zalava et al. 2011). Recently, a beneficial effect of diacerein for the treatment of inflammatory exacerbation caused by SARS-CoV-2 (COVID-19) has also been demonstrated (De Oliveira et al. 2020). The active metabolite, rhein, inhibits pro-inflammatory cytokines, such as TNF- $\alpha$ (Pasin et al. 2010), IL- $1 \alpha$ (Tamura and Ohmori 2001) and IL-1 $\beta$ (Pasin et al. 2010; Abdel-Gaber et al. 2018). In chondrocytes derived from cartilage with osteoarthritis, either diacerein or rhein reduces the number of IL-1R (Martel-Pelletier et al. 1998) as well as IL-1 $\beta$ synthesis (MartelPelletier et al. 1998; Mendes, et al. 2002; Martel-Pelletier and Pelletier 2010). Except for scarce studies on the effect of diacerein on testis under inflammatory conditions (AbdelGaber et al. 2018; Fouad et al. 2020), the effect of this antiinflammatory drug in adult testes under normal conditions has not been addressed. In an attempt to understand the physiological role of cytokines in testes, including LC-TM interplay, we evaluated LC steroidogenic activity, number of ED2 macrophages and seminiferous epithelium integrity in cytokines deficient rat testes.

\section{Material and methods}

\section{Animals and treatment}

The protocol regarding the use and treatment of animals was approved by the Ethical Committee for Animal Research of São Paulo State University (UNESP/FOAr, SP, Brazil; number: 15/2019)) and by the Ethical Committee for Animal Research of São Paulo Federal University (UNIFESP/EPM, SP, Brazil; number: 7383061219). 
Sixteen Holtzman adult male rats (Rattus norvegicus albi$n u s$ ) weighing 250-300 g were maintained in polypropylene cages under $12 \mathrm{~h}$ light and $12 \mathrm{~h}$ dark cycle at controlled temperature $\left(23 \pm 2{ }^{\circ} \mathrm{C}\right)$ and humidity $(65-75 \%)$, with water and food ad libitum.

The animals of diacerein group (DIAG; $n=8$ ) received, by gavage, daily solution of $100 \mathrm{mg} / \mathrm{kg} \mathrm{BW}$ of diacerein (Artrodar ${ }^{\circledR}$; Pharma Indústria Química e Farmacêutica Ltda, Reg.MS:1.0341.0052.002-2, lot: 19I10601) diluted in saline for 30 days, for the induction of anti-inflammatory effect in the animals (Tamura et al. 2002) while the animals of the control group $(\mathrm{CG} ; n=8)$ received saline solution by the same route. This dosage $(100 \mathrm{mg} / \mathrm{kg})$ was used in an attempt to reduce IL-1 $\beta$ and TNF- $\alpha$ (Pasin et al. 2010) without causing adverse toxic effects. This is confirmed by the fact that dosages from 100 to $150 \mathrm{mg} / \mathrm{kg}$ have demonstrated antioxidant effects (Tamura and Ohmori 2001; Bu et al. 2018), alleviating methotrexate-induced hepatotoxicity (Bu et al. 2018). Moreover, high dosages (200/mg/kg-2000 mg/kg) of rhein have also presented non-genotoxic and non-mutagenic effects in rats and mice (Brun 1997).

After treatment, the animals were weighed and anesthetized with $80 \mathrm{mg} / \mathrm{kg}$ BW of ketamine hydrochloride (Francotar, Virbac do Brasil Ind. Com. Ltda, Jurubatuba, Brazil, Reg.MA: 7.885 ) and $8 \mathrm{mg} / \mathrm{kg} \mathrm{BW}$ of xylazine hydrochloride (Virbaxyl; Virbac do Brasil Ind. Com. Jurubatuba, Brazil, Reg.MA:7.899). Blood samples were collected via cardiac puncture directly from the left ventricle with BD Vacutainer ${ }^{\circledR}$ tubes for serum testosterone measurement. Testes were weighed and the relative testicular weights were calculated based on the ratio of absolute testis weight to body weight of each animal. The right testes were fixed for histological evaluation, whereas fragments of the left testes were stored at $-80{ }^{\circ} \mathrm{C}$ for Western blot analysis.

\section{Testosterone measurement}

Serum testosterone (T) levels were determined by chemiluminescence immunoassays, using the Access ${ }^{\circledR} 2$ Immunoassay System (Beckman Coulter, CA, USA) and the Access Testosterone Immunoassay kit (Beckman Coulter, CA, USA). The antibody was specific for testosterone $(\leq 2 \%$ cross-reactivity) and the analytical sensitivity considered was $10 \mathrm{ng} / \mathrm{dL}$. The analysis was performed at the São Lucas Clinical and Microbiological laboratory (Araraquara, SP, Brazil).

\section{Histological procedures}

Testes were cross sectioned at the equatorial plane and fixed for $48 \mathrm{~h}$ in a $4 \%$ formaldehyde (Merck, Germany) buffered with $0.1 \mathrm{M}$ sodium phosphate ( $\mathrm{pH} 7.4)$. The samples were dehydrated in graded concentrations of ethanol and embedded in glycolmethacrylate (Leica Biosystems, Historesin-Embedding Kit, Wetzlar, Germany, lot: 010,284) or paraffin.

The historesin sections ( $3 \mu \mathrm{m}$ thick) were stained with Gill's Hematoxylin and Eosin (H.E) according to Cerri and Sasso-Cerri (2003) for morphological and morphometric analyses. The paraffin sections were subjected to Perls' Prussian blue histochemistry reaction for detection of ferric iron in macrophages. Thus, after deparaffinization, the sections were immersed in acid ferrocyanide solution for $10 \mathrm{~min}$ containing $2 \%$ potassium ferrocyanide and $2 \%$ hydrochloric acid solutions (Bancroft and Stevens 1996). The sections were washed in distilled water, and the nuclear staining was performed with safranin $1 \%$ aqueous solution. Sections were dehydrated and mounted in resinous mounting media.

Paraffin sections were also adhered to silanized slides and submitted to TUNEL (TdT-mediated dUTP-biotin Nick End Labeling) method and immunohistochemistry and immunofluorescence reactions, as described below.

\section{Morphometric analysis of seminiferous tubules and number of SC}

In non-serial H.E-stained testicular sections (distance between sections around $30 \mu \mathrm{m}$ ), the images were captured by a camera DP-71 (Olympus, Tokyo, Japan) coupled to an Olympus BX-51 microscope (Tokyo, Japan). The objective lens used was UPlanSApo $20 \times / 0.75$ for measurement of areas, and UPlanSApo $40 \times / 0.90$ for the quantification of $\mathrm{SC}$ number. The measurements were made using the Image Analysis System-Image Pro-express 6.0 (Olympus, Tokyo, Japan).

\section{Tubular areas and frequency of abnormal tubules}

Since the seminiferous tubules (ST) size is variable according to the stage of the seminiferous cycle, and in an attempt to standardize the tubular sections to be measured, $15 \mathrm{ST}$ exhibiting round shape were randomly selected at specific stages of the seminiferous epithelium cycle, according to Leblond and Clermont (1952), containing, from the basal compartment to the lumen, the following germ cell layers: I-VI (A and Intermediate/B spermatogonia, pachytene (P) spermatocytes, round and elongate spermatids); VII-VIII (A spermatogonia, preleptotene and $\mathrm{P}$ spermatocytes, round and step 19 elongate spermatids); IX-X (post-spermiation stage containing A spermatogonia, leptotene (L) and P spermatocytes and elongating spermatids) and XI-XIV (A spermatogonia, L to secondary spermatocytes and elongating spermatids). Thus, in a total of 60 tubules per animal, the area of the seminiferous epithelium and the area of the total tubular section (tubular area) were measured (Sasso-Cerri 
et al. 2017). The luminal area was obtained by subtracting the total area from the epithelial area.

The number of tubules showing deranged epithelium and/ or containing sloughed germ cells in the lumen was quantified, and the frequency of these abnormal seminiferous tubules was calculated.

\section{Number of SC}

In non-serial testicular sections, thirty-two cross ST sections exhibiting round shape were randomly selected, and the number of Sertoli cell (SC) nuclei showing typical morphology and evident nucleolus was quantified (Caneguim et al. 2009) under an Olympus BX-51 microscope. The number of SC per ST was calculated.

\section{TUNEL method and number of TUNEL-positive cells}

TUNEL method, used for detection of DNA breaks during cell death, was performed as previously described (Caneguim et al. 2009; Beltrame et al. 2019) and according to the ApopTag ${ }^{\circledR}$ peroxidase in situ kit (Millipore; Temecula, CA, USA, lot: 3,098,590) manufacturer instructions.

In non-serial testicular sections (distance between sections around $30 \mu \mathrm{m}$ ), fifty round-shaped ST sections were randomly selected under an Olympus BX-51 microscope (Tokyo, Japan) equipped with a camera DP-71 (Olympus, Tokyo, Japan). In each tubular section, the number of TUNEL-positive germ cells was quantified using an UPlanSApo $40 \times / 0.90$ objective lens. The number of TUNEL-positive cells per ST was calculated.

In 15 fields of non-serial testicular sections per animal, containing interstitial tissue, the tissue area was measured and the number of TUNEL-positive interstitial cells (IC) was quantified in a standardized interstitial area. The number of TUNEL-positive IC per $\mathrm{mm}^{2}$ of interstitial tissue was calculated.

\section{Immunohistochemistry and immunofluorescence reactions}

CD163 (resident ED2 macrophage marker), TNF- $\alpha$ and AR were detected by immunohistochemistry. StAR (steroidogenic acute regulatory protein), 17 $\beta$-HSD (enzyme involved in steroidogenesis), TNF- $\alpha$ and IL- $1 \beta$ (pro-inflammatory cytokines) were detected by immunofluorescence. To confirm the presence of IL- $1 \beta$ in LC, double immunofluorescence reaction for the co-localization of $17 \beta-\mathrm{HSD}$ and IL- $1 \beta$ in the same section was also performed. The validation of the antibodies used in this study is stated in the technical specifications insert provided by the respective manufacturers (cited below).
Sections were immersed in $0.001 \mathrm{M}$ citrate buffer $(\mathrm{pH}$ 6.0) and heated in a microwave oven at $90{ }^{\circ} \mathrm{C}$ for $30 \mathrm{~min}$ for antigen recovery. For detection of CD163, TNF- $\alpha$ and AR by immunohistochemistry, sections were previously immersed in hydrogen peroxide for endogenous peroxidase inactivation. All sections were incubated in $2 \%$ BSA for $30 \mathrm{~min}$, and incubated at $4{ }^{\circ} \mathrm{C}$ overnight with the following primary antibodies: mouse anti-CD163 monoclonal IgG antibody (RRID: AB_321966, 1:800, Bio-Rad, USA; code: MCA342R, lot:00,710); rabbit anti-TNF- $\alpha$ polyclonal IgG antibody (RRID: AB_10891701, 1:500, Boster Biological Technology, Pleasanton - USA; code: PA1079, lot:0101812Da45079125); rabbit anti-AR polyclonal IgG antibody (RRID: AB_633881, 1:1000, Santa Cruz Biotechnology, code: sc-13062, lot:\#D0414); rabbit anti-IL-1 $\beta$ polyclonal IgG antibody (RRID: AB_308765, 1:400, Abcam, Cambridge, Massachusetts-USA; code: ab9722, lot:GR3175415-1), rabbit anti-StAR polyclonal IgG antibody (RRID:AB_2890634, 1:100, Abcam; USA; code: ab203193, lot:GR3192239-3) and mouse anti-17ßHSD7 polyclonal IgG antibody (RRID: AB_2891064, 1:500, Santa Cruz Biotechnology, Dallas, USA; code: sc-393936, lot:\#B0414). Sections incubated with anti-CD163 and antiTNF- $\alpha$ and anti-AR IgG antibodies were washed in PBS and incubated at room temperature with biotinylated anti-mouse IgG and anti-rabbit IgG secondary antibodies and peroxidase-labelled-streptavidin (Universal Dako LSAB Kit, Dako Inc., Carpinteria, CA, USA, Ref: K4061, lot: 10,136,201). The reactions were stained with 3.3'-diaminobenzidine (DAB: Dako Liquid DAB + Substrate Chromogen system, Dako Inc., Carpinteria, CA, USA, Ref: K3468, lot: 10,147,082) and counterstained with Carazzi's haematoxylin. The testicular sections subjected to immunofluorescence reactions were washed in PBS and incubated in the dark with the following secondary antibodies: Alexa Fluor ${ }^{\circledR} 594$ antirabbit IgG antibody (1:500; Invitrogen ${ }^{\circledR}$ by Thermo Fisher Scientific, Calrsbad, USA, code: R3117, lot: $2,086,924)$ or Alexa Fluor ${ }^{\circledR} 488$ anti-mouse IgG antibody (1:1000; Molecular Probes ${ }^{\circledR}$ by Life Technologies, Calrsbad, USA, Ref: A11001, lot: 1,664,729) for $1 \mathrm{~h}$ at room temperature. After washing in PBS, nuclear staining was performed with DAPI (1:500, Molecular Probes by Life Technologies; Carlsbad, CA, USA, Ref: R37606, lot: 1,616,913) for 5 min in the dark at the room temperature and the slides were mounted with Fluoromount ${ }^{\circledR}$ mounting medium (Dako faramount Aqueous mounting medium, Dako Inc., Carpinteria, CA, USA, Ref: S3025, lot: 11,176,284). To check possible unspecific binding of the secondary antibodies to the tissues, negative controls were performed by incubating sections with nonimmune serum instead of primary IgG antibodies. Unspecific immunolabelling was not detected in these testicular sections. 


\section{Number of Perls-stained and CD163-immunolabelled macrophages}

In non-serial testicular sections (distance between sections around $30 \mu \mathrm{m}), 20$ fields of interstitial tissue were randomly selected under an Olympus BX-51 microscope (Olympus, Tokyo, Japan) equipped with a camera DP-71 (Olympus, Tokyo, Japan), and the objective lens used was UPlanSApo 40x/0.90. In these fields, a standardized area of interstitial tissue per animal was measured using an image analysis system (Image Pro-express 6.0 Olympus, Tokyo, Japan). In this area, the number of CD163-positive macrophages exhibiting either weak or strong immunostaining was quantified, and the number of CD163-immunolabelled macrophages per $\mathrm{mm}^{2}$ of interstitial tissue was calculated for each animal. The same procedures were conducted for the quantification of Perlspositive macrophages in 20 fields of non-serial testicular sections subjected to Perls' histochemistry reaction. The number of Perls-stained macrophages $/ \mathrm{mm}^{2}$ of interstitial tissue was calculated.

\section{$17 \beta-H S D$, IL-1 $\beta$ and TNF- $\alpha$ immunofluorescent areas}

Immunofluorescent areas were analyzed using DFC 550 Camera (Leica, Germany) attached to a BM4000 B LED microscope (Leica, Germany) and the Leica Application Suite software (LAS 4.3, Leica, Germany). An objective lens HCX FL Plan 40x/0.65 (Leica, Germany) was used for the measurement of IL-1 $\beta$ and $17 \beta$-HSD immunofluorescent areas in the interstitial tissue, whereas an objective lens HCX FL Plan $20 \times / 0.4065$ (Leica, Germany) was used for the measurement of TNF- $\alpha$ in the ST. All parameters of the software, including exposure, gain and saturation as well as the threshold adjustment and color range, were rigorously standardized for each immunoreaction analyzed so that only areas with intense red or green fluorescence were computed.

In non-serial testicular sections (distance between sections around $30 \mu \mathrm{m})$, IL- $1 \beta$ and $17 \beta$-HSD immunofluorescence was measured in a total standardized interstitial tissue area per animal. In this area, IL-1 $\beta$ and $17 \beta$-HSD immunofluorescent areas were measured and the respective areas/ $\mathrm{mm}^{2}$ of interstitial tissue were calculated.

For the estimation of the TNF- $\alpha$ immunofluorescent area in the ST, the tubular area of around 15 tubules at stages IX-XI was measured since the immunoexpression of TNF- $\alpha$ is stage-specific and more accentuated and specific in IX-XI tubules (De et al. 1993). Thus, in a standardized tubular area of each animal from CG and DIAG, the TNF- $\alpha$ immunofluorescent area was measured, and the immunofluorescent area $/ \mathrm{mm}^{2}$ of seminiferous tubule was calculated (de Santi et al. 2021).

\section{$17 \beta-H S D$ and IL-1 $\beta$ double immunofluorescence}

The double immunofluorescence was performed according to Shum et al. (2013). After antigen recovery as described above, the sections were incubated overnight at $4{ }^{\circ} \mathrm{C}$ with mouse anti-17 $\beta$-HSD7 polyclonal IgG antibody (RRID: AB_2891064, 1:500, Santa Cruz Biotechnology, Dallas, USA: sc-393936, lot: \#B0414). The day after, the sections were washed and incubated with Alexa Alexa Fluor ${ }^{\circledR} 488$ anti-mouse IgG antibody (1:1000; Molecular Probes ${ }^{\circledR}$ by Life Technologies, Calrsbad, USA, Ref: A11001, lot: $1,664,729)$, for $1 \mathrm{~h}$ at room temperature. After washings in PBS, the sections were incubated with rabbit anti-IL-1 $\beta$ polyclonal IgG antibody (RRID: AB_308765, 1:400, Abcam, Cambridge, Massachusetts-USA; code: ab9722, lot: GR3175415-1) overnight at $4{ }^{\circ} \mathrm{C}$ with. The day after (third day), the sections were washed in high salt PBS and incubated in Alexa Fluor ${ }^{\circledR} 594$ anti-rabbit IgG antibody (1:500; Invitrogen $\AA$ by Thermo Fisher Scientific, Calrsbad, USA, code: R3117, lot:2,086,924) for $1 \mathrm{~h}$ at room temperature. After washing in PBS, nuclear staining was performed with DAPI (1:500, Molecular Probes by Life Technologies; Carlsbad, CA, USA, Ref: R37606, lot:1,616,913) for $5 \mathrm{~min}$ in the dark at the room temperature, and the slides were mounted with Fluoromount ${ }^{\circledR}$ mounting medium (Dako faramount Aqueous mounting medium, Dako Inc., Carpinteria, CA, USA, Ref: S3025, lot: 11,176,284). Negative controls were performed following the same protocol and steps, except the incubations in primary antibodies (anti-IL1 $\beta$ and anti-17 $\beta$ HSD); during these steps, the sections were incubated in non-immune serum from the same species as the secondary antibodies (Burry 2011). Unspecific immunolabelling was not detected in the testicular sections.

The immunofluorescence was analyzed using DFC 550 Camera (Leica, Germany) attached to a BM4000 B LED microscope (Leica, Germany) and the Leica Application Suite software (LAS 4.3, Leica, Germany). The images were captured using an objective lens HCX FL Plan 40x/0.65 (Leica, Germany).

\section{Western Blot}

Frozen testes samples were homogenized with lysis buffer (50 mM Tris pH 8.0, $150 \mathrm{mM} \mathrm{NaCl,} 1 \mathrm{mM}$ EDTA, 10\% glycerol, $1 \%$ Triton $\mathrm{X}-100,1 \mathrm{mM}$ phenylmethylsulfonyl fluoride (PMSF) and $5 \mathrm{ng} / \mathrm{mL}$ of each protease inhibitors: Pepstatin, Leupeptin, Aprotinin, Antipain and Chymostatin (Sigma-Aldrich, code: P834-1ML, lot: \#014M4024V) and maintained overnight at $4{ }^{\circ} \mathrm{C}$. After centrifugation for $20 \mathrm{~min}$ at $8,944 \mathrm{~g}$, the supernatant was collected, and the measurement of protein concentration was performed by Bradford (Sigma-Aldrich, St. Louis, EUA; Ref: B6916, lot: SLBP3810V) assay. Protein samples (30 $\mu \mathrm{g})$ were 
separated in $10 \%$ SDS-PAGE and transferred to a nitrocellulose membrane $0.2 \mu \mathrm{m}$ (Bio-Rad Laboratories, Hercules, California, USA, cat: \#1,620,112, lot: A10236173). The membranes were treated for $1 \mathrm{~h}$ with blocking solution containing 5\% non-fat dry milk diluted in PBS/T (PBS/0.2\% Tween 20) for nonspecific blocking and incubated overnight at $4^{\circ} \mathrm{C}$ with the following primary antibodies: rabbit antiIL-1 $\beta$ polyclonal IgG antibody (RRID: AB_308765, 1:400, Abcam, Cambridge, Massachusetts-USA; code: ab9722, lot:GR3175415-1), mouse anti-17 $\beta$-HSD7 polyclonal IgG antibody (RRID: AB_2891064, 1:500, Santa Cruz Biotechnology, Dallas, USA: sc-393936, lot: \#B0414) and rabbit anti-AR polyclonal IgG antibody (RRID: AB_633881, 1:1000, Santa Cruz Biotechnology, code: sc-13062, lot:\#D0414) diluted in blocking solution. After washes in PBS/T, membranes were incubated with HRP conjugated anti-rabbit IgG secondary antibody (1:9000; Sigma-Aldrich, St. Louis, USA, code: A9169-2ML, lot: \#117M4808V), diluted in blocking solution for $1 \mathrm{~h}$ at room temperature. The reactions were detected using enhanced chemiluminescence system (ECL Chemilumin; Boster, AR1170, PI:0,121,569, lot: BST14B12B70). As positive controls, the membranes were stripped and re-probed with rabbit anti- $\beta$-tubulin monoclonal IgG antibody (RRID: AB_10866289, 1:8000; Sigma-Aldrich, USA, code: ab108342, lot:GR275162-10) or rabbit anti-actin IgG antibody (1:8000; Sigma-Aldrich, USA, cod: A2066, lot: \#103M4826V). The assays were performed in triplicate for CG and DIAG.

In the Ponceau-stained membrane, all bands were identified. The optical density (OD) of the band intensities of each lane (total protein) and the OD of the proteins of interest were quantified using Image Lab software (version 5.2.1, Bio-Rad). The results were obtained according to the normalized data using GraphPad Prism ${ }^{\circledR} 6.0$ software (GraphPad Software, CA, USA).

\section{Statistical analysis}

The statistical analysis of the morphometric data was performed using the GraphPad Prism ${ }^{\circledR} 6.0$ software (GraphPad Software, CA, USA). The data were checked for normal distribution by the Kolmogorov and Smirnov's normality test and, according to the data distribution, the differences between the groups were submitted to the unpaired Student's $t$ test. The accepted level of significance was $p \leq 0.05$, and the results were expressed as mean \pm standard deviation.

\section{Results}

\section{Testicular weight}

The body weight of animals from diacerein group (DIAG) were similar to those of control group (CG). However, either absolute or relative testes weight reduced significantly $(p=0.0002$ and $p=0.0476)$ in the animals from DIAG in comparison with CG (Table 1).

\section{Seminiferous epithelium integrity and number of SC}

In the animals from CG, the ST showed regular outline and normal epithelium with organized concentric layers of germ cells (spermatogonia, spermatocytes, round and elongating spermatids) and absence of detached cells in the lumen (Fig. 2a, c). Typical SC and spermatogonia nuclei with evident nucleolus were found in the basal compartment adjacent to the peritubular tissue (Fig. 2c-e). In the DIAG animals, the ST were apparently smaller than CG and showed disorganized epithelium, lack of germ cells, intraepithelial spaces and germ cells filling the lumen (Fig. 2b, f, i, j). Some germ cells, mainly spermatogonia and spermatocytes, showed irregular nuclei and/or condensed chromatin in the nuclear periphery, suggesting apoptosis (Fig. 2h, j). Abnormal SC nuclei with irregular outline were observed; some of them were abnormally located in the tubular lumen (Fig. 2g, j). The number of SC nuclei reduced significantly $(p=0.0002)$ in the animals from DIAG in comparison with CG (Fig. 2k).

\section{Tubular areas and frequency of ST with morphological changes}

A significant reduction of total tubular $(p=0.0005)$ and epithelial $(p=0.0001)$ areas was detected in the testes of animals from DIAG. No difference ( $p=0.6915)$ was observed in the luminal area of treated animals in comparison with CG (Table 1). The frequency of ST with morphological

Table 1 Body weight $(B W)$, absolute testicular weight $(A T W)$, relative testicular weight $(R T W)$, total tubular area (TA), tubular lumen area $(L A)$ and seminiferous epithelium area $(E A)$ of the animals from CG and DIAG

\begin{tabular}{|c|c|c|c|c|c|c|}
\hline & $\mathrm{BW}(\mathrm{g})$ & ATW $(\mathrm{g})$ & RTW(\%) & $\mathrm{TA}\left(\mu \mathrm{m}^{2}\right)$ & $\mathrm{LA}\left(\mu \mathrm{m}^{2}\right)$ & $\mathrm{EA}\left(\mu \mathrm{m}^{2}\right)$ \\
\hline CG & $423 \pm 25.9$ & $1.81 \pm 0.02$ & $0.43 \pm 0.02$ & $82,166.85 \pm 2712.16$ & $8764.51 \pm 1564.41$ & $73,402.34 \pm 1868.11$ \\
\hline DIAG & $425 \pm 17.8$ & $1.61 \pm 0.03 *$ & $0.37 \pm 0.01 *$ & $71,288.79 \pm 3367.80 *$ & $9309.14 \pm 2512.48$ & $61,979.64 \pm 2296.48^{*}$ \\
\hline
\end{tabular}

$*_{p}<0.05$ 

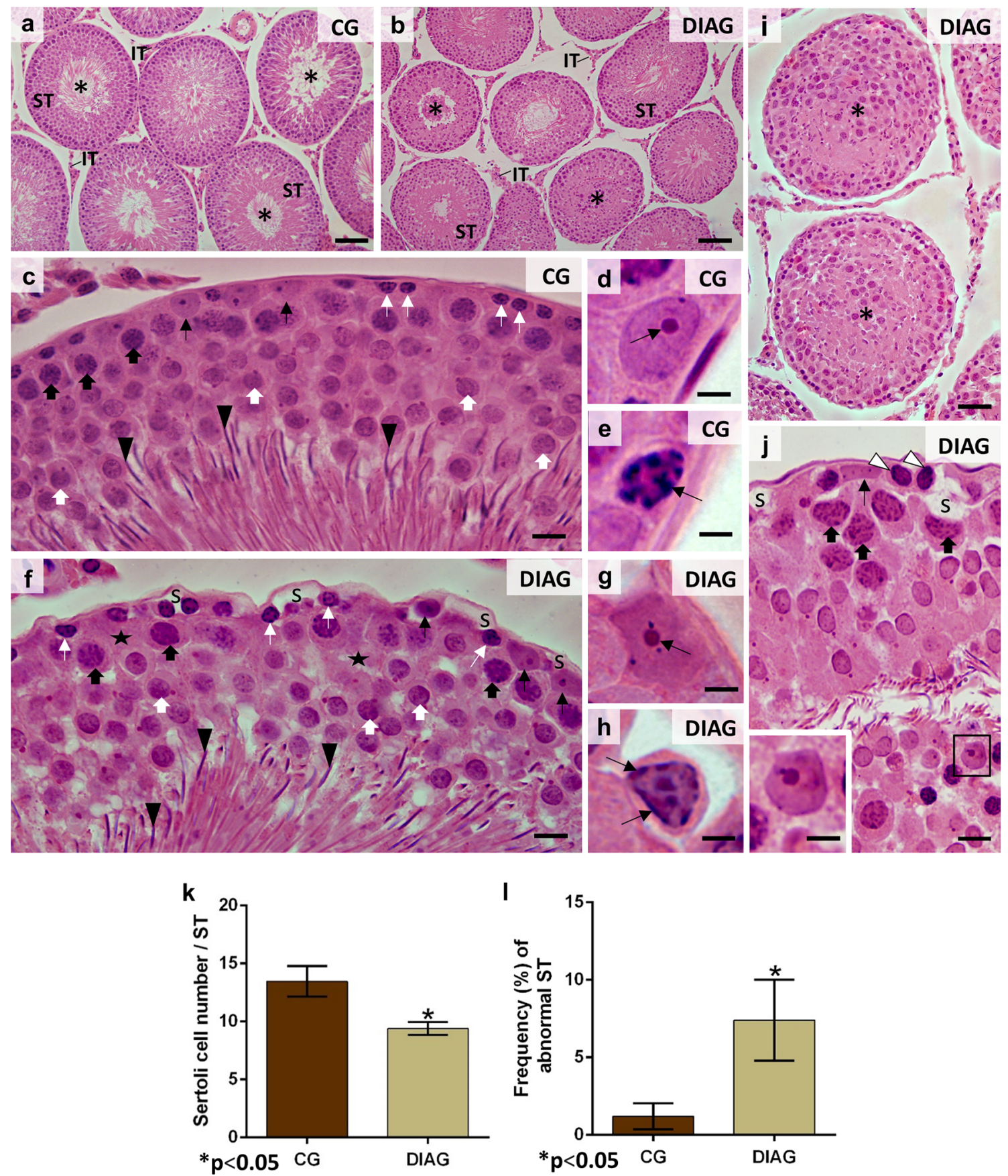

Fig. 2 Photomicrographs of testicular sections of animals from CG and DIAG stained with H.E. $(\mathbf{a}-\mathbf{j})$, number of SC $(\mathbf{k})$ and frequency of abnormal ST (I). In a and $\mathbf{b}$, seminiferous tubules (ST) and interstitial tissue (IT) are observed. In a, the normal seminiferous tubules show empty lumen (asterisks) whereas in $\mathbf{b}$, the tubular sections are apparently smaller than CG and some of them show detached germ cells filling the lumen (asterisks). In c, f, portions of tubules showing germ cells organized in concentric layers: spermatogonia (thin white arrows), spermatocytes (thick black arrows), round spermatids (thick white arrows), elongate spermatids (arrowheads) and SC nuclei with evident nucleolus (thin black arrows) are also observed. In d, a SC nucleus with typical morphology and evident nucleolus (arrow). In e, a spermatogonia with ovoid nucleus containing condensed dots of chromatin (arrow). In $\mathbf{f}$, intraepithelial spaces (S), lack of germ cells in some portions of epithelium (stars) and basophilic SC nuclei (thin

black arrows) are observed. In $\mathbf{g}$, a SC nucleus with evident nucleolus (arrow) shows irregular shape. In $\mathbf{h}$, nucleus of spermatogonium with irregular shape and masses of condensed chromatin in the nuclear periphery (arrows), suggesting apoptosis. In $\mathbf{i}$ and $\mathbf{j}$, tubules showing disorganized epithelium and lumen filled with germ cells (asterisks). In $\mathbf{j}$, a portion of tubule showing intraepithelial spaces (S), leptotene spermatocytes with condensed chromatin in the nuclear periphery (white arrowheads) and pachytene spermatocytes with irregular nucleus (black thick arrows). Note an abnormal flattened SC nucleus (thin arrow). In the lumen, a SC nucleus (inset) is observed among several sloughed germ cells. In $\mathbf{k}$, the number of SC per seminiferous tubule is significantly reduced in DIAG. In $\mathbf{l}$, a significant increase of frequency of abnormal tubules is seen in DIAG. Scale bars $=100 \mu \mathrm{m}$ (a and b); $50 \mu \mathrm{m}(\mathbf{i}), 12 \mu \mathrm{m}(\mathbf{c}, \mathbf{f}$ and $\mathbf{j})$ and $4 \mu \mathrm{m}(\mathbf{d}, \mathbf{e}, \mathbf{g}, \mathbf{h}$, and inset of $\mathbf{j}$ ) 
changes increased significantly in DIAG $(p=0.0043)$ when compared with CG (Fig. 21).

\section{TUNEL-positive cells in the seminiferous epithelium}

In the ST of animals from CG, scarce TUNEL-positive germ cells were found (Fig. 3a). However, in DIAG, numerous TUNEL-positive germ cells, mainly spermatocytes, were observed in the seminiferous epithelium (Fig. 3b, c, d). Detached germ cells in the lumen were also labelled by TUNEL (Fig. 3c). SC nuclei exhibiting TUNEL positivity were also found either in the basal compartment or in the tubular lumen (Fig. 3e, f). The number of TUNEL-positive germ cells increased significantly
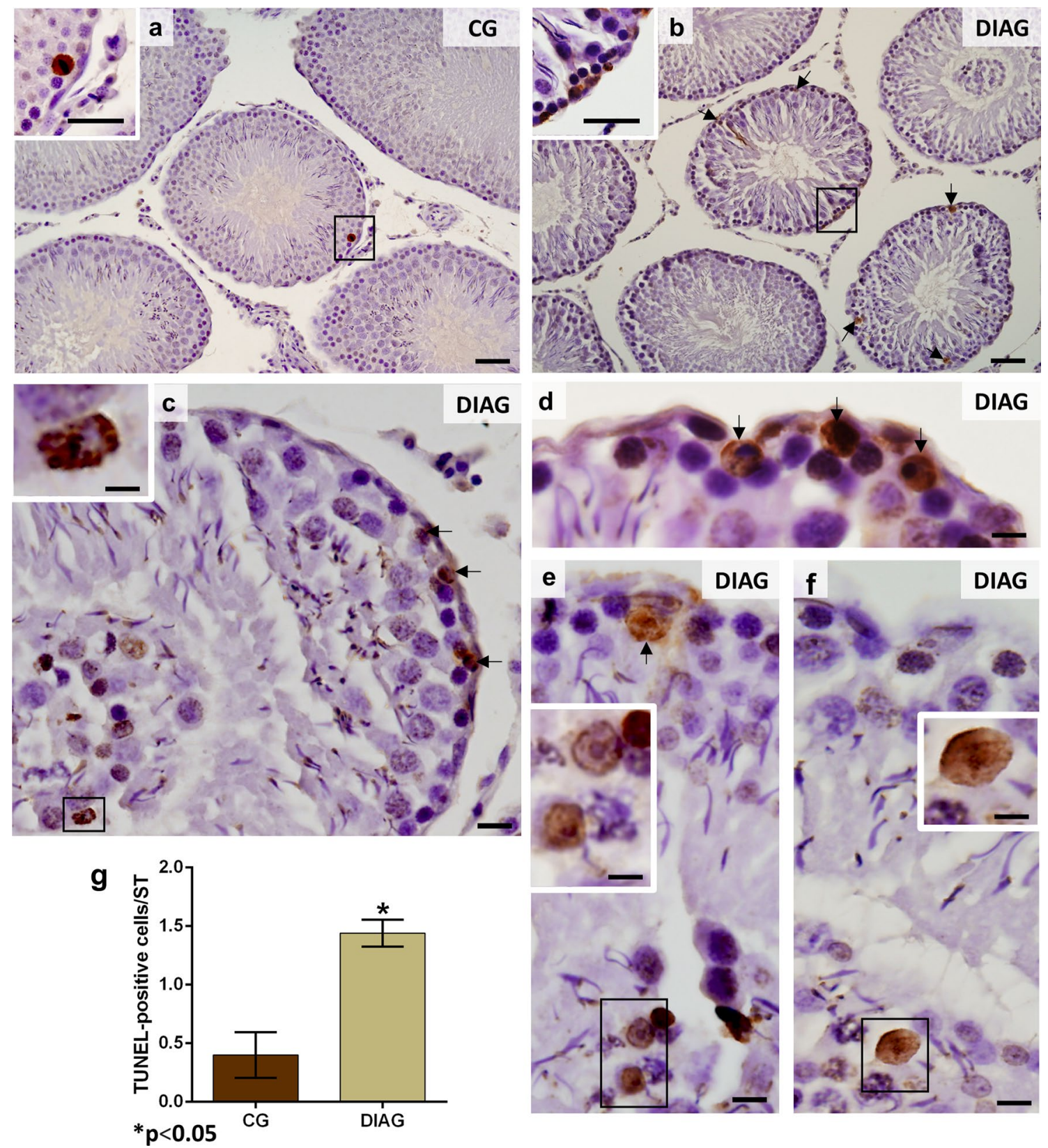

Fig. 3 Photomicrographs of testicular sections submitted to TUNEL method counterstained with haematoxylin $(\mathbf{a}-\mathbf{f})$ and number of TUNEL-positive germ cells (g) in CG and DIAG. In a, scarce TUNEL-positive cells are observed in the tubules of animals from CG. A TUNEL-labelled germ cell is observed (inset). In $\mathbf{b}$, numerous TUNEL-positive cells are observed in the tubules (arrows and inset). In $\mathbf{c}$ and $\mathbf{d}$, TUNEL-positive spermatocytes are observed in the basal

compartment (arrows), and some sloughed germ cells in the lumen are also labelled (c; inset). In $\mathbf{e}$ and $\mathbf{f}$, TUNEL-positive SC nuclei are observed either in the basal compartment (arrow) or in the tubular lumen (insets). In $\mathbf{g}$, the number of TUNEL-positive cells per ST is significantly higher in DIAG than in CG. Scale bars $=70 \mu \mathrm{m}$ (a and b and insets), $13 \mu \mathrm{m}(\mathbf{c}), 8 \mu \mathrm{m}$ (d, e and f) and $4 \mu \mathrm{m}$ (inset: c, e and f) 

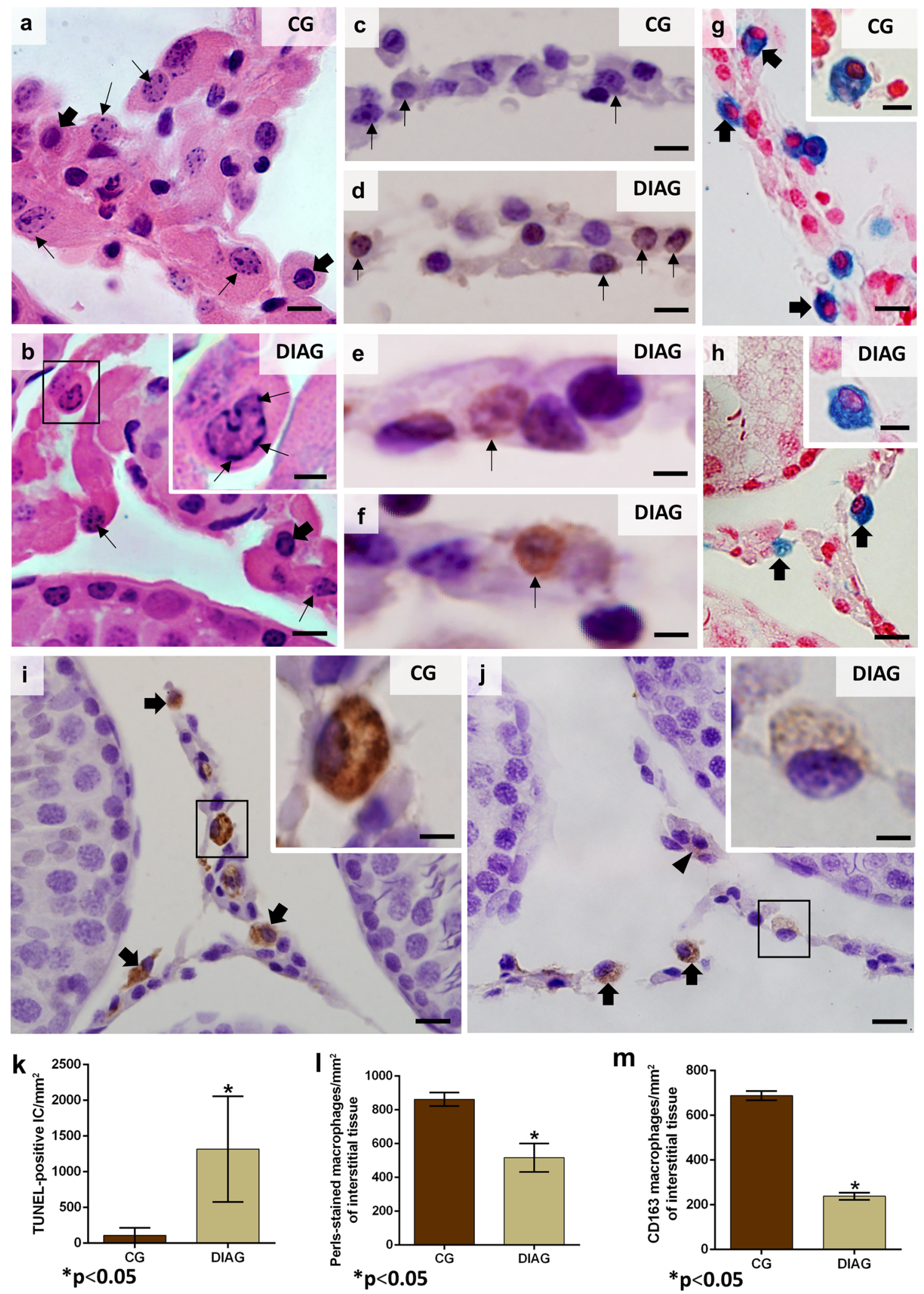
4Fig. 4 Photomicrographs of interstitial tissue of animals from CG and DIAG stained with H.E. a and b TUNEL method (c-f), Perls' histochemical reaction (g and $\mathbf{h}), \mathrm{CD}-163$ immunohistochemistry (i and j), number of TUNEL-positive interstitial cells (IC) (k), number of Perls-stained macrophages (l) and number of CD163-immunolabelled macrophages (m). In a, portions of interstitial tissue showing Leydig cells with typical nucleus exhibiting condensed chromatin dots in the nuclear periphery (thin arrows). Macrophages show eccentric round to ovoid nucleus with intense basophilia (thick arrows). In $\mathbf{b}$, the Leydig cells show nucleus with irregular outline and apparently smaller (thin arrows and inset) than in a. Some of them show condensed masses of chromatin in the nuclear periphery (inset). A macrophage is observed (thick arrow). In c, no TUNEL labelling is observed in Leydig cells (thin arrows) in comparison to several TUNEL-positive Leydig cells observed in DIAG (d-f; thin arrows). In $\mathbf{g}$ and $\mathbf{h}$, Perlsstained macrophages are observed (thick arrows and inset); note that in $\mathbf{h}$, few macrophages are seen. In $\mathbf{i}$ and $\mathbf{j}$, CD163-immunolabelled macrophages are seen (thick arrows and inset); however, in $\mathbf{j}$, some of them are weakly immunolabelled (arrwoheads; inset). In $\mathbf{k}$, the number of TUNEL-positive IC are increased in DIAG in comparison to CG. In $\mathbf{l}$ and $\mathbf{m}$, either the number of CD163-immunolabelled macrophages or the number of Perls-stained macrophages per $\mathrm{mm}^{2}$ of interstitial tissue decreased significantly in DIAG. Scale bars $=8 \mu \mathrm{m}$ $(\mathbf{a}, \mathbf{b}, \mathbf{c}, \mathbf{d}$, inset: $\mathbf{g}$ and $\mathbf{h}) ; 13 \mu \mathrm{m}(\mathbf{g}, \mathbf{h}, \mathbf{i}$ and $\mathbf{j})$, and $4 \mu \mathrm{m}(\mathbf{e}, \mathbf{f}$, inset: $\mathbf{b}, \mathbf{i}$ and $\mathbf{j})$

$(p=0.0001)$ in the animals from DIAG in comparison with CG (Fig. 3g).

\section{Impact of diacerein on interstitial cells (IC)}

In the interstitial tissue of animals from CG, the LC showed normal features such as ovoid to elliptical nucleus with loose chromatin (weak basophily), evident nucleolus and several dots/clumps of chromatin in the nuclear periphery (Fig. 4a). Among groups of LC, macrophages exhibiting eccentric and intense basophilic round to ovoid nucleus with homogenous and compacted chromatin (intense basophily) were also found either in CG or DIAG (Fig. 4a, b). In DIAG, LC nuclei with irregular outline were observed; some of them showed masses of condensed chromatin in the nuclear periphery, typical of apoptosis (Fig. 4b). In the testicular sections submitted to TUNEL method, scarce TUNEL-positive IC were observed in CG whereas several TUNEL-labelled IC were found in DIAG (Fig. 4c-f, k).

In the interstitial tissue of testes of animals from $\mathrm{CG}$ and DIAG, either Perls-positive macrophages (Fig. 4g, h) or CD163-immunolabelled macrophages (Fig. 4i, j) were found in CG and DIAG. However, in DIAG, few positive macrophages to Perls' histochemistry and to CD163 immunohistochemistry were found in comparison to $\mathrm{CG}$ (Fig. 4h, j). Moreover, a weak CD163 immunolabelling was observed in some macrophages of animals from DIAG (Fig. 4j). The quantitative analysis showed a significant decrease in the number of both Perls-stained $(p=0.0001)$ and CD163-immunolabelled $(p=0.0001)$ macrophages in the animals from DIAG (Figs. 4l, m).

\section{Steroidogenic proteins and T levels}

In $\mathrm{CG}$, an enhanced StAR immunofluorescence was observed filling the LC cytoplasm throughout the interstitial tissue (Fig. 5a, c) whereas a weak StAR immunoexpression was restricted to some Leydig cells in DIAG (Fig. 5b, d). The steroidogenic enzyme $17 \beta$-HSD was also detected in the LC of both CG and DIAG groups (Fig. 5e, f). However, in DIAG, these cells showed weak 17 $\beta$-HSD immunolabelling (Fig. 5f) when compared to CG (Fig. 5e). The immunofluorescent area of $17 \beta-\mathrm{HSD} / \mathrm{mm}^{2}$ of interstitial tissue in the animals from DIAG reduced significantly ( $p=0.0001)$ compared to CG (Fig. 5g). Moreover, the Western blot showed weak signals of $17 \beta$-HSD protein levels, which reduced significantly $(p=0.0019)$ in the testicular extracts of animals from DIAG (Fig. 5h).

The serum T levels of animals from DIAG also reduced significantly $(p=0.0131)$ in comparison with CG (Fig. 5i).

\section{Effect of diacerein on IL-1 $\beta$ immunoexpression}

In the testicular sections of animals from both CG and DIAG groups, IL-1 $\beta$ immunoreaction was detected in the interstitial cells (Fig. 6a, b). However, whereas an intense IL-1 $\beta$ immunofluorescence was observed filling the cytoplasm of almost all interstitial cells in CG (Fig. 6a), a weak immunoexpression was observed in few interstitial cells of the animals from DIAG (Fig. 6b). This weak immunoexpression was confirmed by the analysis of IL- $1 \beta$ immunofluorescent area, which reduced significantly $(p=0.0001)$ in DIAG (Fig. 6e). Moreover, the analysis by Western blot showed weak signal of pro-IL-1 $\beta$ protein levels, which reduced significantly in the testicular extracts of animals from DIAG (Fig. 6f).

\section{Co-localization of $17 \beta-H S D$ and IL-1 $\beta$}

Either in the testes of animals from CG or DIAG, the double immunoreaction confirmed that besides macrophages and other interstitial cell types, IL-1 $\beta$ was also detected in $17 \beta$-HSD-immunolabelled LC, evidenced by the co-localization of both proteins in LC (yellow fluorescence; Fig. 6c, d).

\section{AR and TNF- $a$ immunoexpression}

In the testes of animals from $\mathrm{CG}$, an evident AR nuclear immunolabelling was observed either in SC (Fig. 7a) or LC (Fig. 7c). However, in DIAG, scarce SC (Fig. 7b) and LC 


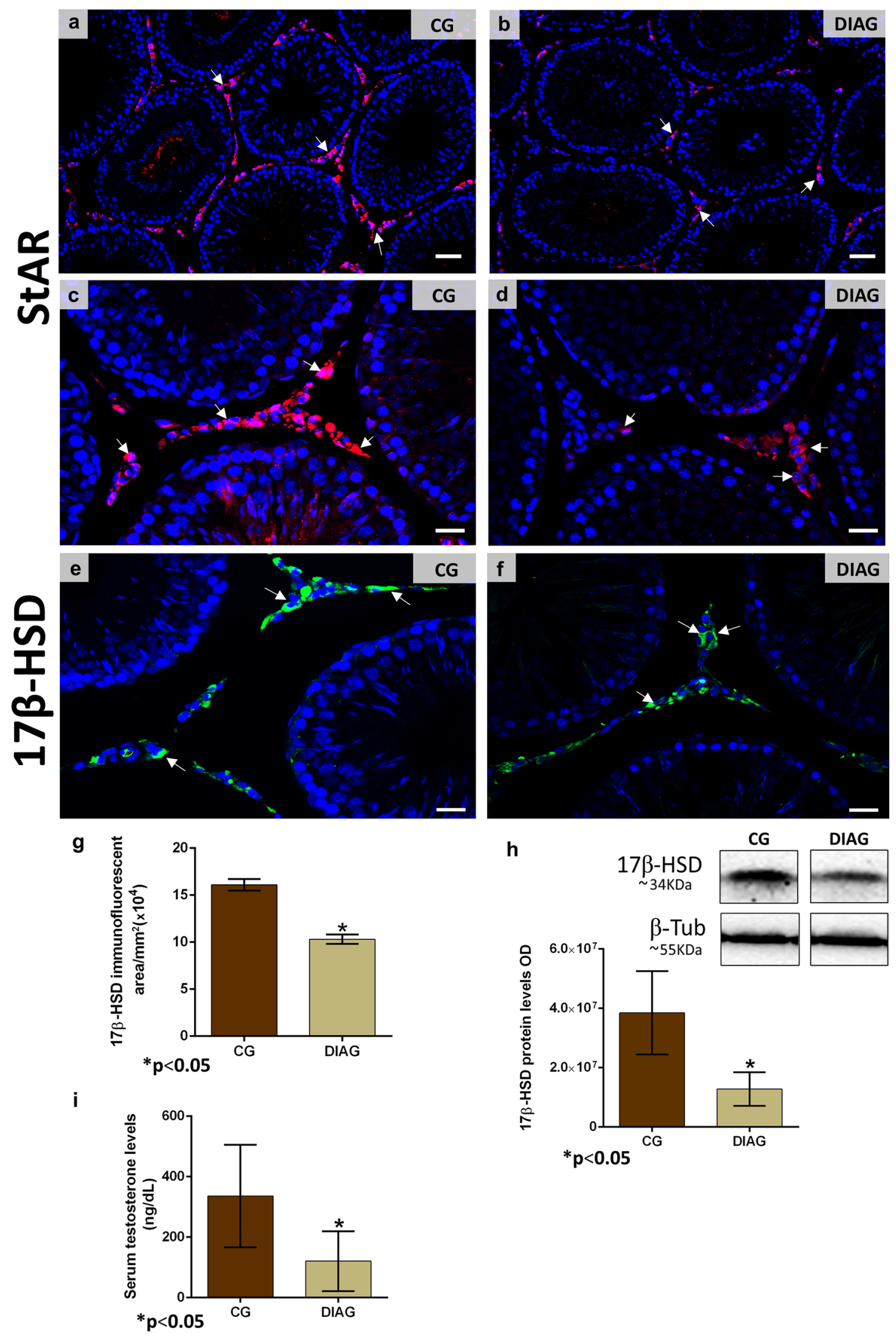


४Fig. 5 Photomicrographs of testicular sections subjected to immunofluorescence for detection of StAR (a-d) and 17 $\beta$-HSD (e and f), area of $17 \beta$-HSD immunofluorescence (g), 17 $\beta$-HSD protein levels by Western blot (h) and serum $\mathrm{T}$ levels (i). In $\mathbf{a}$ and $\mathbf{c}$, the interstitial tissue shows intense masses of StAR immunofluorescence filling the LC cytoplasm (arrows). In $\mathbf{b}$ and $\mathbf{d}$, a weak StAR immunofluorescence is noted only in some LC of the interstitial tissue (arrows). In e, the interstitial tissue shows intense 17 $\beta$-HSD immunofluorescence in the LC cytoplasm (arrows) whereas in f, a weak 17 $\beta$-HSD immunolabelling is observed in LC (arrows). In $\mathbf{g}$, a significant reduction in the $17 \beta$-HSD immunofluorescence area per $\mathrm{mm}^{2}$ of interstitial tissue is observed in DIAG. In $\mathbf{h}$, a strong $17 \beta-\mathrm{HSD}$ signal at $34 \mathrm{KDa}$ is observed in CG whereas a weak signal is noted in DIAG. $\beta$-tubulin signal is observed in both groups. A significant decrease of $17 \beta$ HSD levels optical density (OD) is observed in the animals from DIAG when compared to CG. In $\mathbf{i}$, the serum $\mathrm{T}$ levels is significantly decreased in DIAG. Scale bars $=75 \mu \mathrm{m}(\mathbf{a}$ and $\mathbf{b}) ; 26 \mu \mathrm{m}(\mathbf{c}-\mathbf{f})$

(Fig. 7d) immunostained nuclei were found. The analysis by Western blot showed weak signals of AR protein levels, which reduced significantly $(p=0.0170)$ in the testicular extracts of animals from DIAG (Fig. 7i). The TNF- $\alpha$ immunohistochemistry showed a strong immunolabelling in spermatocytes and elongating spermatids in the animals from CG whereas a weak immunoreaction was detected in DIAG (Figs. 7e, f). TNF- $\alpha$ immunofluorescence was also detected in the seminiferous tubules of CG and DIAG (Figs. 7g, h). However, the tubules at stages IX-XI showed an intense TNF- $\alpha$ immunofluorescence in the cytoplasm of spermatocytes and elongating spermatids (Fig. $7 \mathrm{~g}$ ) whereas a weak or absent immunoreaction was detected in these cells of the animals from DIAG (Fig. 7h). The quantitative analysis showed a significant reduction $(p=0.0001)$ in the TNF- $\alpha$ immunofluorescent area of IX-XI seminiferous tubules (Fig. 7j).

\section{Discussion}

There is scarce information on the effect of cytokines in testes under normal conditions. In this study, we used diacerein to reduce IL- $1 \beta$ and TNF- $\alpha$ levels in adult rat testes in an attempt to investigate the impact of these cytokines deficiency on testicular steroidogenesis and spermatogenesis. In the diacerein-treated rats, a significant reduction of IL- $1 \beta$ and TNF- $\alpha$ immunoexpression was detected in the interstitial tissue and seminiferous tubules, respectively. This deficiency was associated with changes in ED2 macrophages (TM) and LC, including weak AR immunoexpression in LC, which culminated in low steroidogenic activity, confirmed by decrease in StAR and $17 \beta-$ HSD immunoexpression and low serum $\mathrm{T}$ levels. Therefore, the low steroidogenesis caused by diacerein-induced dysfunction on TM-LC interplay may be responsible for the changes in the seminiferous epithelium. However, considering SC death in association with the weak AR immunoexpression in these cells and reduced intra-tubular TNF- $\alpha$ immunoexpression, it is possible that the diacerein-induced androgenic dysfunction in SC may be related to TNF- $\alpha$ deficiency, as discussed below.

\section{Impact of diacerein on LC and macrophages}

LC nuclei with irregular outline and condensed chromatin in the nuclear periphery, suggesting apoptosis, were observed in DIAG. These findings were in agreement with the presence of TUNEL-positive LC and the significant increase in the number of TUNEL-positive interstitial cells. Moreover, reduction in the immunoexpression of $17 \beta-\mathrm{HSD}$, weak StAR immunofluorescence and decreased serum $\mathrm{T}$ levels confirmed that the treatment impaired steroidogenesis in LC. Studies in vitro, in which LC were stimulated by LPS, have shown IL-1 $(\alpha / \beta)$ mRNA expression in these cells (Wang et al. 1991; Lin et al. 1993; Hedger et al. 2005). In the present study, the IL- $1 \beta$ and $17 \beta-H S D$ double immunoreaction confirmed an evident IL-1 $\beta$ immunoexpression in LC of animals from CG and DIAG. However, in DIAG, either the IL- $1 \beta$ immunofluorescent area in the interstitial tissue or the testicular IL- $1 \beta$ protein levels reduced significantly. Although studies have demonstrated a direct correlation between high levels of cytokines and low $\mathrm{T}$ levels and/or steroidogenesis under inflammatory conditions (Ogilvie et al. 1999; Tremellen et al. 2018), suppression of steroidogenesis and low testicular T levels have been demonstrated in TNF- $\alpha$ knockout mice (Suh et al. 2008). Moreover, studies have demonstrated that IL-1 stimulates steroidogenesis in LC (Verhoeven et al. 1988; Warren et al. 1990; Manna et al. 2007) as well as in granulosa-lutein cells (Dang et al. 2017). According to Manna et al. (2007), IL-1 $\alpha$ upregulates StAR expression and stimulates steroidogenesis in LC under normal conditions (Fig. 1). Here, the reduction of IL- $1 \beta$ in parallel to weak AR immunoexpression in LC as well as decreased StAR, 17 $\beta$-HSD immunolabelling and $\mathrm{T}$ levels reinforces the idea that IL- $1 \beta$ mediates steroidogenesis in LC (Fig. 8). 

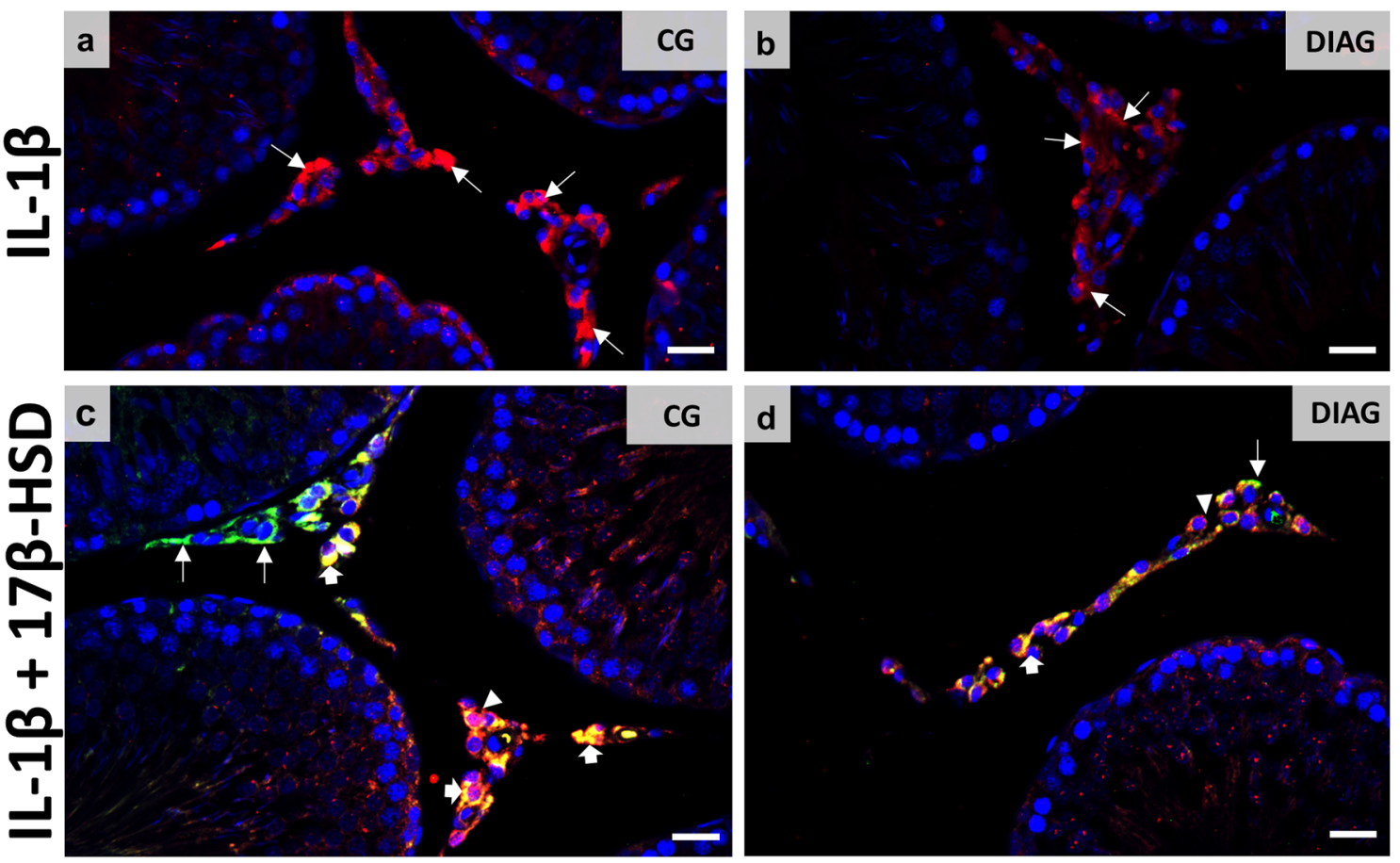

e

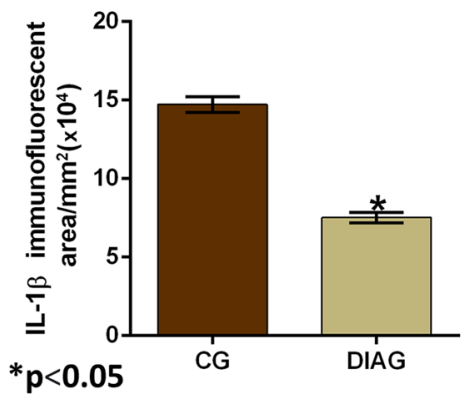

Fig. 6 Photomicrographs of testicular sections of animals showing IL-1 $\beta$ immunofluorescence (a and $\mathbf{b})$ and double immunofluorescence for detection of $17 \beta$-HSD and IL- $1 \beta$ in animals from CG and DIAG (c and d), IL-1 $\beta$ immunofluorescence area (e) and IL-1 $\beta$ protein levels by Western blot (f). In a, intense IL-1 $\beta$ immunofluorescence is observed filling the cytoplasm of several interstitial cells (arrows) whereas in d, a weak immunoreaction is restricted to few cells of interstitial tissue (arrows). In $\mathbf{c}$ and a, Leydig cells showing only 17 $\beta$-HSD immunofluorescence (green fluorescence; thin arrows) are observed. Some of them (yellow fluorescence; thick arrows) show

Studies have demonstrated that diacerein impairs the formation of NLRP3 multiprotein complex, inhibiting the production of caspase- 1 , an interleukin- $1 \beta$-converting enzyme (ICE), reducing the production of active IL-1 $\beta$

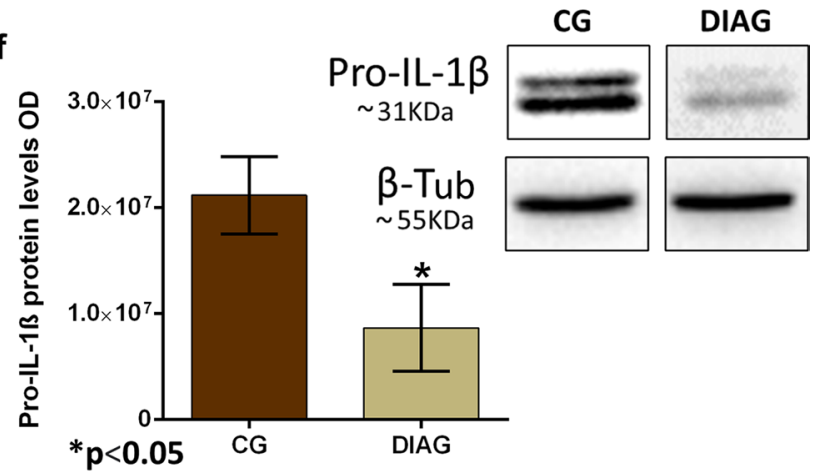

double immunolabelling (IL-1 $\beta$ and $17 \beta$-HSD) whereas macrophages and other interstitial cells exhibit only IL-1 $\beta$ (red fluorescence; arrowheads). In $\mathbf{e}$, a significant reduction in the IL-1 $\beta$ immunofluorescence area per $\mathrm{mm}^{2}$ of interstitial tissue is observed in DIAG compared to CG. In f, Western blot analysis shows strong IL- $1 \beta$ signal at $31 \mathrm{KDa}$ in CG whereas a weak signal is noted in DIAG. $\beta$-tubulin signal is observed in both groups. A significant decrease of IL-1 $\beta$ levels optical density (OD) is observed in the animals from DIAG when compared to CG. Scale bars $=26 \mu \mathrm{m}(\mathbf{a}, \mathbf{b}, \mathbf{c}$ and $\mathbf{d})$

(Chang et al. 2019; Moldovan et al. 2000) (Fig. 8). It is known that IL-1 $(\alpha / \beta)$ acts on TM via autocrine signaling (Dinarello et al. 1987; Wang et al. 1991), and mediates the translocation of NF-kB to nucleus where genes for the 
expression of pro-IL1 $\beta$ (O'Bryan and Hedger 2008) and TNF- $\alpha$ (O'Bryan and Hedger 2008; Dorrington and Fraser 2019) are activated (Fig. 1). In chondrocytes in vitro, the suppression of IL-1 $\beta$ impairs the degradation of I $\kappa$ B- $\alpha$, avoiding the subsequent activation of NF-kB (Martel-Pelletier et al. 1998; Mendes et al. 2002; Martel-Pelletier and Pelletier 2010). Therefore, considering the weak immunoexpression of IL1 $\beta$ observed in DIAG, associated with low number of ED2 TM and 17 $\beta$-HSD immunoexpression, it is conceivable to suggest that IL- $1 \beta$ deficiency impaired the autocrine signaling in TM and/or the TM-LC paracrine interactions (Fig. 8).

ED2 (CD163) macrophages play important role in the control of steroidogenesis under normal (Lukyanenko et al. 2001; Mossadegh-Keller et al. 2017; MossadeghKeller and Sieweke 2018) and inflammatory (Gaytan et al. 1995) conditions. The close contact between TM and LC is essential for the transport of several factors, including 25-hydroxycholesterol and 25-hydroxylase from macrophages to LC (Lukyanenko et al. 2001) (Fig. 1). Moreover, an in vitro study under normal conditions has shown that IL- $1 \beta$, produced by TM, stimulates steroidogenesis in LC via paracrine signaling (Verhoeven et al. 1988) (Fig. 1), and reduction in the TM population impairs testosterone synthesis (Verhoeven et al. 1988; Hutson 2006). In the present study, either the number of CD163-positive TM or Perls-stained TM reduced significantly in the animals from DIAG. These findings may be associated with the impaired steroidogenesis following diacerein treatment (Fig. 8). On the other hand, studies have demonstrated that destruction of LC with ethane dimethane sulfonate (EDS) impairs TM population (Schlatt et al. 1999), confirming that LC are essential for the maintenance of TM. Studies have demonstrated a proportional correlation between T levels and MIF (Meinhardt et al. 1998; Hedger et al. 2005), which is also produced by LC (Meinhardt et al. 1996). Since MIF induces monocytes/macrophages recruitment in testes (Hedger 2002), we cannot omit the fact that MIF levels may be reduced in DIAG due to impaired steroidogenesis/low T levels; this possible effect may also explain the reduction in the number of CD163positive TM (Fig. 8). Considering that MIF also acts in macrophages via $\mathrm{CD} 74$ receptor and regulates the activation of NLRP3 complex, which induces the conversion of pro-IL- $1 \beta$ into active IL- $1 \beta$ by the interleukin converting enzyme caspase-1 (Shin et al. 2019) (Fig. 1), low MIF levels could also have disturbed the production of IL- $1 \beta$. Therefore, besides a direct inhibitory effect of diacerein on NLRP3, low MIF levels could also have disturbed the production of IL-1 $\beta$. Further analyses focusing on MIF levels of diacerein-treated rats are necessary to clarify this hypothesis.

\section{Impact of androgen and/or cytokines deficiency on ST}

Besides the interstitial tissue, the integrity of the seminiferous tubules was also affected following diacerein treatment. A high frequency of tubules with disorganized germ cell layers and/or detached germ cells filling the lumen was observed. Moreover, a high index of germ cells death was observed in DIAG animals, and the number of SC decreased in these animals. These results corroborated the significant reduction either in the tubular and epithelial areas and subsequent decrease in testicular weight observed in the animals from DIAG. It is known that androgens are essential for the seminiferous epithelium and spermatogenic process (Smith and Walker 2014). Several studies have demonstrated a direct correlation between low serum $\mathrm{T}$ levels (due to impaired steroidogenesis and/or LC) and damage to the seminiferous epithelium, including SC integrity (Beltrame et al. 2019; Câmara et al. 2019). In the present study, the testes of animals from DIAG showed low AR protein levels as well as weak AR immunolabelling either in SC or LC in comparison with CG. Therefore, the tubular changes observed in DIAG may be consequence of both androgen deficiency (low T levels) and androgen dysfunction in SC due to weak AR immunoexpression. However, studies have demonstrated that either SC or germ cells express cytokines such as IL- $1 \alpha$ and TNF- $\alpha$ under normal (Gérard et al. 1991; Suominen et al. 2004) and inflammatory (Cudicini et al. 1997; Loveland et al. 2017) conditions. Under normal conditions, IL- $1 \alpha$ produced by SC seems to play a role in the conversion of glucose into lactate for germ cells, maintaining spermatogenesis (Hedger and Meinhardt 2003). It is important to emphasize that diacerein inhibits either IL-1 $\alpha$ (Tamura and Ohmori 2001) or IL-1 $\beta$ (Pasin et al. 2010; Abdel-Gaber et al. 2018) in inflammatory processes. Therefore, although IL1- $\alpha$ levels were not evaluated in this study, we cannot exclude the fact that the tubular changes observed in DIAG may also be consequence of a possible IL-1 $\alpha$ deficiency induced by diacerein. Besides the participation of IL- $1 \alpha$ in SC, TNF- $\alpha$ mRNA has been detected in pachytene spermatocytes and round spermatids (De et al. 1993; Suominen et al. 2004), and this cytokine seems to mediate SC functions via TNFR1/TNFR2 receptors (Suominen et al. 2004). In SC in vitro, TNF- $\alpha$ increases 

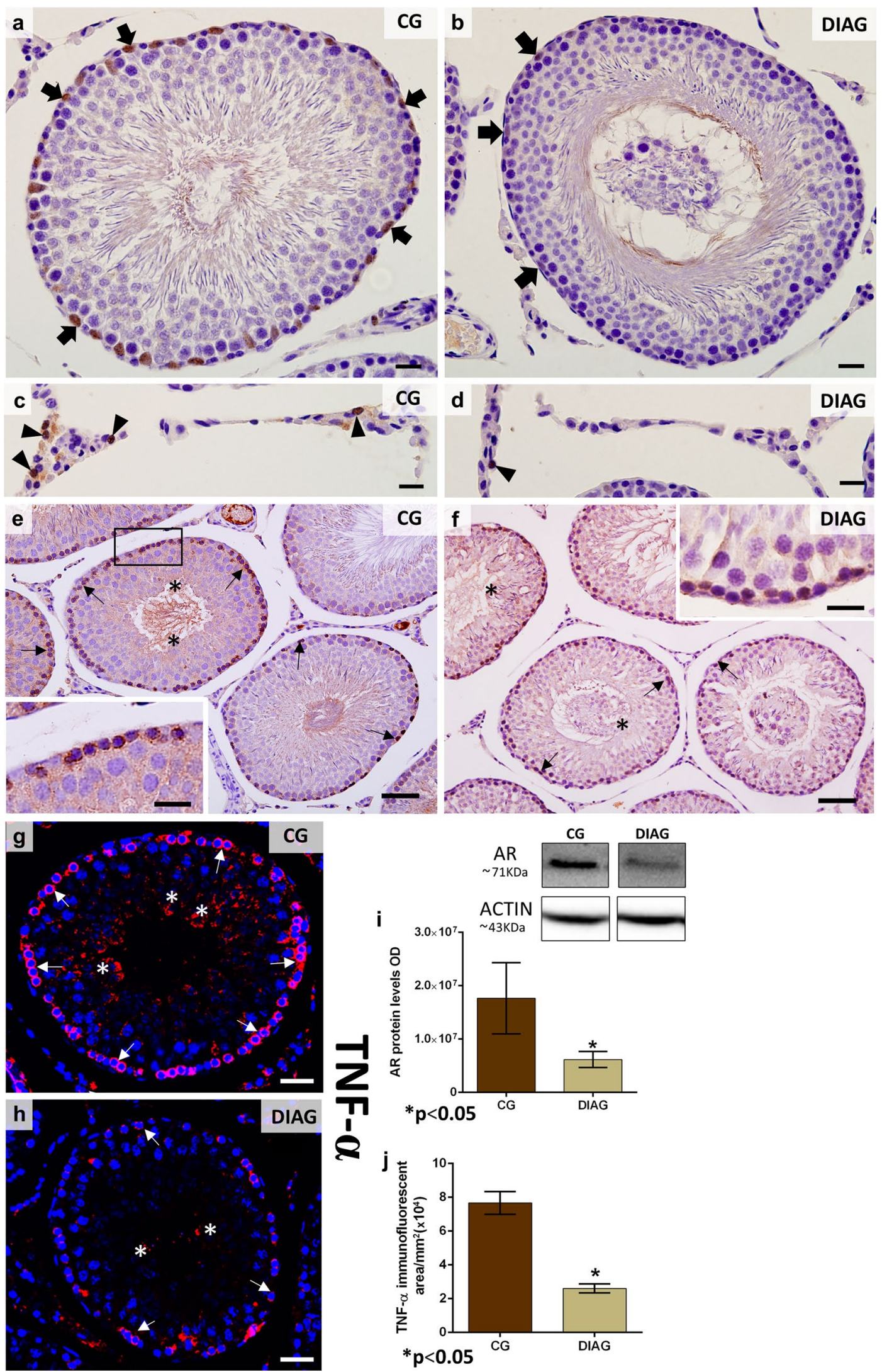
4Fig. 7 Photomicrographs of testicular sections of animals from CG and DIAG submitted to immunohistochemistry for detection of AR (a-d) and TNF- $\alpha$ (e and f) and TNF- $\alpha$ immunofluorescence (g and h), AR protein levels by Western blot (i) and area of TNF- $\alpha$ immunofluorescence (j). In a, evident AR immunostaining is observed in the SC nuclei throughout the basal compartment of the ST (arrows), whereas in b, only few AR-immunostained SC nuclei are seen (arrows). In $\mathbf{c}$ and $\mathbf{d}$, the interstitial tissue shows AR-immunolabelled LC (arrowheads); note that in $\mathbf{d}$ (DIAG), scarce AR-immunostained LC (arrowheads) are observed in comparison to CG. In e, strong TNF- $\alpha$ immunolabelling is observed in spermatocytes (arrows and inset) and elongating spermatids (asterisks). In $\mathbf{f}$, note the weak immunoreaction observed either in the basal (arrows and inset) or in the adluminal (asterisks) compartments. In $\mathbf{g}$, a seminiferous tubule at stages IX-XI shows evident TNF- $\alpha$ immunofluorescence in the cytoplasm of spermatocytes (thin arrows) and elongating spermatids (asterisks) whereas in $\mathbf{h}$, weak or absent TNF- $\alpha$ immunolabelling is noted in these cells of a IX-XI tubule of animal from DIAG. In $\mathbf{i}$, Western blot analysis of AR levels in testicular extracts shows strong band at $71 \mathrm{KDa}$ in $\mathrm{CG}$ in comparison with weak band in DIAG. Actin signal is observed in both groups. A significant decrease in AR levels optical density (OD) is observed in the animals from DIAG. In $\mathbf{j}$, TNF- $\alpha$ immunofluorescence area per $\mathrm{mm}^{2}$ of seminiferous epithelium at stages IX-XI is significantly reduced in DIAG in comparison with CG. Scale bars $=25 \mu \mathrm{m}$ (a and b); $20 \mu \mathrm{m}$ (c and d); $70 \mu \mathrm{m}$ (e and f), $30 \mu \mathrm{m}(\mathbf{g}$ and $\mathbf{h})$ and $13 \mu \mathrm{m}$ (insets: $\mathbf{e}$ and $\mathbf{f})$

the activity of lactate dehydrogenase (Nehar et al. 1997). Moreover, TNF- $\alpha$ seems to inhibit apoptosis via regulation of FasL (CD95L), acting as a survival factor for germ cells, maintaining germ cells viability (Pentikäinen et al. 2001). In testes of TNF- $\alpha$ knockout mice, steroidogenesis is suppressed in response to reduced expression of steroidogenesis-related genes, and spermatogenesis and sperm production are also impaired probably due to low testicular T levels (Suh et al. 2008). Our results are in agreement with these findings since a significant reduction in TNF- $\alpha$ immunoexpression was observed in parallel to changes in ST of animals from DIAG, including germ cells death and damage to SC. According to Delfino et al. (2003), the expression of AR, an essential receptor for the responsiveness of SC to androgens, seems to be regulated by TNF- $\alpha$ since this factor stimulates AR promoter and induces AR expression in SC in vitro. Therefore, the low testicular AR protein levels verified in DIAG associated with the weak AR immunolabelling in SC confirm the androgenic dysfunction in the seminiferous epithelium, and the decrease of TNF- $\alpha$ in germ cells, caused by diacerein, may be responsible for this process.

In conclusion, diacerein reduced IL- $1 \beta$ and TNF- $\alpha$ in testes of rats under normal conditions. The diacerein-induced IL-1 $\beta$ deficiency in the interstitial cells was associated with reduction in the number of TM, low immunoexpression of steroidogenic proteins, LC death and reduction in testosterone levels, reinforcing the idea that this cytokine plays a role in LC steroidogenesis. Considering the TM-LC interplay, the changes in TM may be responsible for LC dysfunction, which in turn may impairs TM. The low steroidogenesis explains SC and germ cells death; however, the weak immunoexpression of TNF- $\alpha$ and AR in germ cells and SC, respectively, point to a role of this cytokine on the androgenic control of SC and maintenance of spermatogenesis. Further analyses are necessary to confirm this hypothesis. 


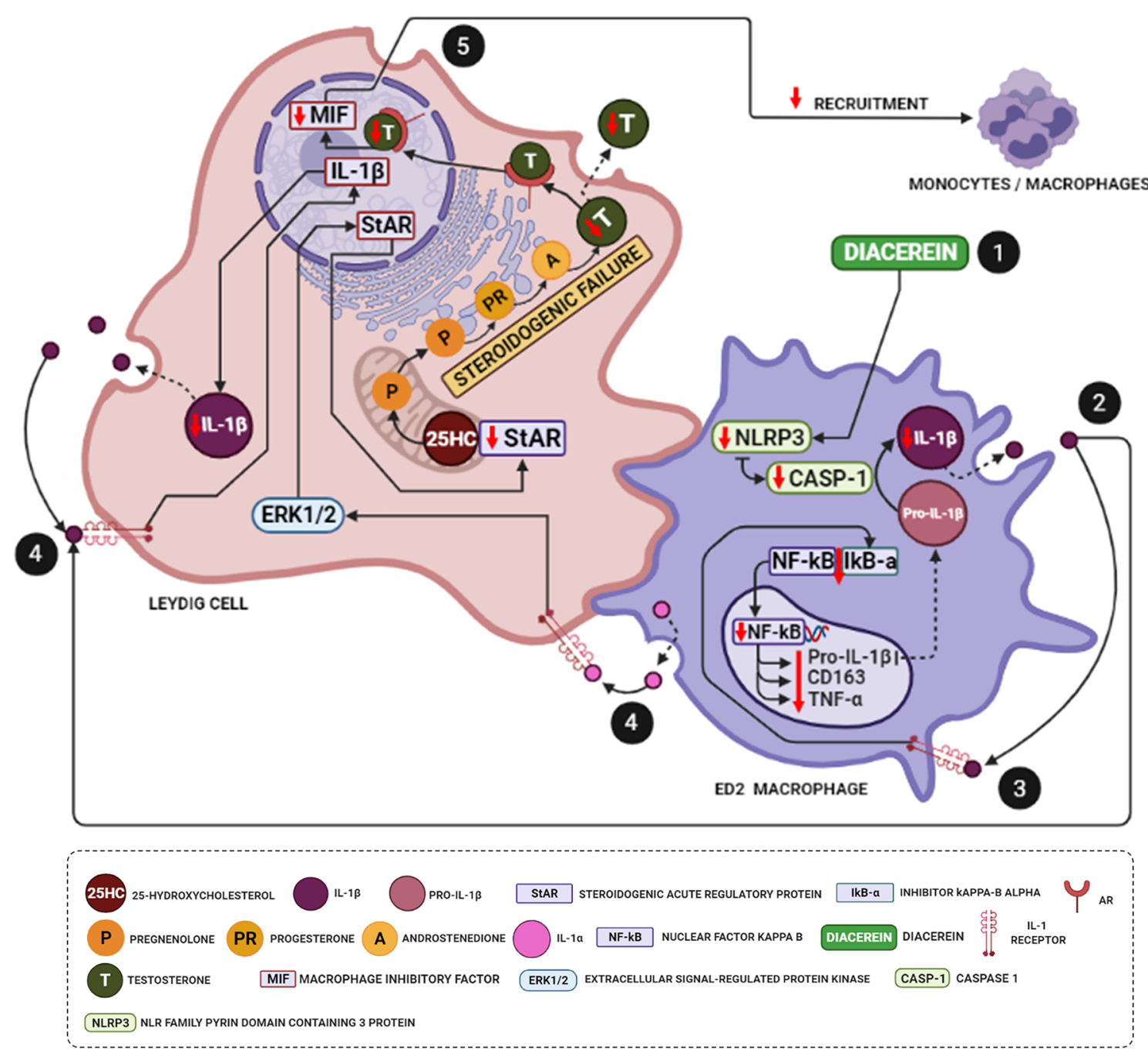

Fig. 8 Changes in Leydig cell (LC) and ED2 testicular macrophage (TM) induced by diacerein based on the literature and findings of this study. 1-) Diacerein inhibits NLRP3 complex and subsequent caspase-1 (CASP-1), impairing the conversion of pro-IL-1 $\beta$ into active IL-1 $\beta$. 2-) Low IL-1 $\beta$ levels impairs IL autocrine action in TM and/ or paracrine signaling in LC. 3-) In TM, NF-kB activation is impaired

Acknowledgements The authors thank Pedro Sérgio Simões for the histological technical assistance. The authors also thank Fabiane de Santi for her assistance during Western blot assays.

Author contribution ES-C coordinated the study. SAO. ES-C and PSC carried out the treatment of animals and the histological processing. SAO carried out the immunoreactions, Western blot, morphometry and statistical analyses. SAO and ES-C carried out the TUNEL method. SAO and ES-C selected the images and SAO made the schematic figures. SAO, ES-C and PSC participated in the manuscript design. All the authors participated in the critical analysis and interpretation of results, and contributed to the writing and revising of the manuscript.

Funding This research was supported by FAPESP (2017/19829-6), CNPq and CAPES (code 001). by low IL- $1 \beta$ levels, downregulating the expression of pro-IL-1 $\beta$, CD163 and TNF- $\alpha$. 4-) In LC, reduced IL- $\alpha / \beta$ levels impair the auto induction of IL-1 $\beta$ via autocrine signaling and downregulate the expression of StAR via ERK1/2, impairing steroidogenesis. 5-) It is possible that low $\mathrm{T}$ levels downregulate MIF expression, reducing monocytes/macrophages recruitment (Created using BioRender.com)

Data availability All data generated or analysed during this study are included in this published article

\section{Declarations}

Conflict of interest The authors declare that there is no conflict of interest that could be perceived as prejudicing the impartiality of the research reported.

\section{References}

Abdel-Gaber SA, Mohammed RK, Refaie MMM (2018) Mechanism mediating the protective effect of diacerein in 
ischemia-reperfusion-induced testicular injury in rats. Life Sci 209:57-62. https://doi.org/10.1016/j.lfs.2018.07.060

Bancroft JD, Stevens A (1996) Theory and practice of histological techniques. Churchill Livingstone

Beattie MC, Adekola L, Papadopoulos V, Chen H, Zirkin BR (2015) Leydig cell aging and hypogonadism. Exp Gerontol 68:87-91. https://doi.org/10.1016/j.exger.2015.02.014

Beltrame FL, De Santi F, Vendramini V, Cabral RE, Miraglia SM, Cerri PS, Sasso-Cerri E (2019) Vitamin B12 prevents cimetidineinduced androgenic failure and damage to sperm quality in rats. Front Endocrinol 10:1-16. https://doi.org/10.3389/fendo.2019. 00309

Bornstein SR, Rutkowski H, Vrezas I (2004) Cytokines and steroidogenesis. Mol Cell Endocrinol 215:135-141. https://doi.org/10. 1016/j.mce.2003.11.022

Brun PH (1997) Effect of diacetylrhein on the development of experimental osteoarthritis. A Biochemical Investigation. Osteoarthr Cartilage 5:289-291. https://doi.org/10.1016/s1063-4584(97) 80025-8

Bu T, Wang C, Meng Q, Huo X, Sun H, Sun P, Zheng S, Liu Z, Liu K (2018) Hepatoprotective effect of rhein against methotrexateinduced liver toxicity. Eur J Pharmacol 834:266-273. https://doi. org/10.1016/j.ejphar.2018.07.031

Burry RW (2011) Controls for immunocytochemistry: an update. J Histochem Cytochem 59:6-12. https://doi.org/10.1369/jhc.2010. 956920

Câmara ML, Almeida TB, de Santi F, Rodrigues BM, Cerri PS, Beltrame FL, Sasso-Cerri E (2019) Fluoxetine-induced androgenic failure impairs the seminiferous tubules integrity and increases ubiquitin carboxyl-terminal hydrolase L1 (UCHL1): possible androgenic control of UCHL1 in germ cell death? Biomed Pharmacother 109:1126-1139. https://doi.org/10.1016/j.biopha.2018. 10.034

Caneguim BH, Cerri PS, Spolidório LC, Miraglia SM, Sasso-Cerri E (2009) Structural alterations in the seminiferous tubules of rats treated with immunosuppressor tacrolimus. Reprod Biol Endocrinol 7:1-9. https://doi.org/10.1186/1477-7827-7-19

Cerri PS, Sasso-Cerri E (2003) Staining methods applied to glycol methacrylate-embedded tissue sections. Micron 34:365-372

Chang WC, Chu MT, Hsu CY, Wu YJJ, Lee JY, Chen TJ, Chung WH, Chen DY, Hung SI (2019) Rhein, an anthraquinone drug, suppresses the NLRP3 inflammasome and macrophage activation in urate crystal-induced gouty inflammation. Am J Chin Med 47:135-151. https://doi.org/10.1142/S0192415X19500071

Cudicini C, Lejeune H, Gomez E, Bosmans E, Ballet F, Saez J, Jégou B (1997) Human Leydig cells and Sertoli cells are producers of interleukins-1 and-6. J Clin Endocrinol Metab 82:1426-1433. https://doi.org/10.1210/jcem.82.5.3938

Dang X, Zhu Q, He Y, Wang Y, Lu Y, Li X, Qi J, Wu H, Sun Y (2017) Il-1b upregulates star and progesterone production through the erk1/2-and p38-mediated creb signaling pathways in human granulosa-lutein cells. Endocrinology 158:3281-3291. https://doi. org/10.1210/en.2017-00029

De Oliveira PG, Termini L, Durigon EL, Lepique AP, Sposito AC, Boccardo E (2020) Diacerein: a potential multi-target therapeutic drug for COVID-19. Med Hypotheses 144:109920. https://doi.org/ 10.1016/j.mehy.2020.109920

De Santi F, Beltrame FL, Rodrigues BM, Junior M, Scaramele NF, Lopes FL, Cerri PS, Sasso-Cerri E (2021) Venlafaxine-induced damage to seminiferous epithelium, spermiation, and sperm parameters in rats: a correlation with high estrogen levels. Andrology 9:297-311. https://doi.org/10.1111/andr.12852

De SK, Chen H-L, Pace JL, Hunt JS, Terranova PF, Enders GC (1993) Expression of tumor necrosis factor-alpha in mouse spermatogenic cells. Endocrinology 133:389-396. https://doi.org/10.1210/ endo.133.1.8319585
DeFalco T, Potter SJ, Williams AV, Waller B, Kan MJ, Capel B (2015) Macrophages contribute to the spermatogonial niche in the adult testis. Cell Rep 12:1107-1119. https://doi.org/10.1016/j.celrep. 2015.07.015

Delfino FJ, Boustead JN, Fix C, Walker WH (2003) NF-кB and TNF- $\alpha$ stimulate androgen receptor expression in Sertoli cells. Mol Cell Endocrinol 201:1-12. https://doi.org/10.1016/s0303-7207(03) 00005-4

Dinarello CA, Ikejima T, Warner SJ, Orencole SF, Lonnemann G, Cannon JG, Libby P (1987) Interleukin 1 induces interleukin 1. I. Induction of circulating interleukin 1 in rabbits in vivo and in human mononuclear cells in vitro. J Immunol 139:1902-1910

Dorrington MG, Fraser IDC (2019) NF-кB signaling in macrophages: dynamics, crosstalk, and signal integration. Front Immunol 10:705. https://doi.org/10.3389/fimmu.2019.00705

Fouad AA, Abdel-Aziz AM, Hamouda AAH (2020) Diacerein downregulates NLRP3/Caspase-1/IL-1 $\beta$ and IL-6/STAT3 pathways of inflammation and apoptosis in a rat model of cadmium testicular toxicity. Biol Trace Elem Res 195:499-505. https://doi.org/10. 1007/s12011-019-01865-6

Fujiwara Y, Komohara Y, Ikeda T, Takeya M (2011) Corosolic acid inhibits glioblastoma cell proliferation by suppressing the activation of signal transducer and activator of transcription- 3 and nuclear factor-kappa B in tumor cells and tumor-associated macrophages. Cancer Sci 102:206-211. https://doi.org/10.1111/j. 1349-7006.2010.01772.x

Gaytan F, Bellido C, Morales C, Reymundo C, Aguilar E, van Rooijen N (1995) Response to Leydig cell apoptosis in the absence of testicular macrophages. J Reprod Immunol 29:81-94. https://doi. org/10.1016/0165-0378(95)00934-d

Gérard N, Syed V, Bardin W, Genetet N, Jégou B (1991) Sertoli cells are the site of interleukin- $1 \alpha$ synthesis in rat testis. Mol Cell Endocrinol 82:R13-R16. https://doi.org/10.1016/0303-7207(91) 90019-0

Gerendai I, Banczerowski P, Csernus V (2005) Interleukin 1- $\beta$ injected into the testis acutely stimulates and later attenuates testicular steroidogenesis of the immature rat. Endocrine 28:165-170. https:// doi.org/10.1385/ENDO:28:2:165

Haseeb A, Chen D, Haqqi TM (2013) Delphinidin inhibits IL-1 $\beta$ induced activation of NF- $\mathrm{KB}$ by modulating the phosphorylation of IRAK-1Ser376 in human articular chondrocytes. Rheumatology 52:998-1008. https://doi.org/10.1093/rheumatology/kes363

Hedger MP (1997) Testicular leukocytes: what are they doing? Rev Reprod 2:38-47. https://doi.org/10.1530/ror.0.0020038

Hedger MP (2002) Macrophages and the immune responsiveness of the testis. J Reprod Immunol 57:19-34. https://doi.org/10.1016/ s0165-0378(02)00016-5

Hedger MP, Meinhardt A (2003) Cytokines and the immune-testicular axis. J Reprod Immunol 58:1-26. https://doi.org/10.1016/s01650378(02)00060-8

Hedger M, Klug J, Fröhlich S, Müller R, Meinhardt A (2005) Regulatory cytokine expression and interstitial fluid formation in the normal and inflamed rat testis are under Leydig cell control. J Androl 26:379-386. https://doi.org/10.2164/jandrol.04149

Hutson JC (2006) Physiologic interactions between macrophages and Leydig cells. Exp Biol Med 231:1-7. https://doi.org/10.1177/ 153537020623100101

Ikejima M, Marsischky G, Gill DM (1987) Direction of elongation of poly(ADP-ribose) chains. Addition of residues at the polymeraseproximal terminus. J Biol Chem 262:17641-17650

Indumathy S, Pueschl D, Klein B, Fietz D, Bergmann M, Schuppe HC, Da Silva N, Loveland BE, Hickey MJ, Hedger MP, Loveland KL (2020) Testicular immune cell populations and macrophage polarisation in adult male mice and the influence of altered activin A levels. J J Reprod Immunol 142:103204. https://doi.org/10. 1016/j.jri.2020.103204 
Leblond CP, Clermont Y (1952) Definition of the stages of the cycle of the seminiferous epithelium in the rat. Ann N Y Acad Sci 55:548-573. https://doi.org/10.1111/j.1749-6632.1952.tb26576.x

Leite NC, Viegas BB, Villela-Nogueira CA, Carlos FO, Cardoso C, Salles GF (2019) Efficacy of diacerein in reducing liver steatosis and fibrosis in patients with type 2 diabetes and non-alcoholic fatty liver disease: a randomized, placebo-controlled trial. Diabetes Obes Metab 21:1266-1270. https://doi.org/10.1111/dom. 13643

Lin T, Wang D, Nagpal ML (1993) Human chorionic gonadotropin induces interleukin-1 gene expression in rat Ley dig cells in vivo. Mol Cell Endocrinol 95:139-145. https://doi.org/10.1016/03037207(93)90039-m

Loveland KL, Klein B, Pueschl D, Indumathy S, Bergmann M, Loveland BE, Hedger MP, Schuppe HC (2017) Cytokines in male fertility and reproductive pathologies: immunoregulation and beyond. Front Endocrinol 8:1-16. https://doi.org/10.3389/fendo. 2017.00307

Lukyanenko YO, Chen JJ, Hutson JC (2001) Production of 25-hydroxycholesterol by testicular macrophages and its effects on Leydig cells. Biol Reprod 64:790-796. https://doi.org/10.1095/biolreprod 64.3.790

Manna PR, Jo Y, Stocco DM (2007) Regulation of Leydig cell steroidogenesis by extracellular signal-regulated kinase $1 / 2$ : role of protein kinase A and protein kinase C signaling. J Endocrinol 193:53-63. https://doi.org/10.1677/JOE-06-0201

Martel-Pelletier J, Pelletier JP (2010) Effects of diacerein at the molecular level in the osteoarthritis disease process. Ther Adv Musculoskelet Dis 2:95-104. https://doi.org/10.1177/1759720X09359104

Martel-Pelletier J, Mineau F, Jolicoeur FC, Cloutier JM, Pelletier JP (1998) In vitro effects of diacerhein and rhein on interleukin 1 and tumor necrosis factor- $\alpha$ systems in human osteoarthritic synovium and chondrocytes. J Rheumatol 25:753-762

Meinhardt A, Bacher M, McFarlane JR, Metz CN, Seitz J, Hedger MP, De Kretser DM, Bucala R (1996) Macrophage migration inhibitory factor production by Leydig cells: evidence for a role in the regulation of testicular function. Endocrinology 137:5090-5095. https://doi.org/10.1210/endo.137.11.8895383

Meinhardt A, Bacher M, Metz C, Bucala R, Wreford N, Lan H, Atkins R, Hedger M (1998) Local regulation of macrophage subsets in the adult rat testis: examination of the roles of the seminiferous tubules, testosterone, and macrophage-migration inhibitory factor. Biol Reprod 59:371-378. https://doi.org/10.1095/biolreprod 59.2.371

Meinhardt A, Wang M, Schulz C, Bhushan S (2018) Microenvironmental signals govern the cellular identity of testicular macrophages. J Leukoc Biol 104:757-766. https://doi.org/10.1002/JLB.3MR03 18-086RR

Mendes AF, Caramona MM, De Carvalho AP, Lopes MC (2002) Diacerhein and rhein prevent interleukin-1 $\beta$-induced nuclear factor- $\mathrm{\kappa B}$ activation by inhibiting the degradation of inhibitor $\kappa B-\alpha$. Pharmacol Toxicol 91:22-28. https://doi.org/10.1034/j. 1600-0773.2002.910104.x

Moldovan F, Pelletier J, Jolicoeur FC, Cloutier JM, Martel-Pelletier J (2000) Diacerhein and rhein reduce the ICE-induced IL-1 $\beta$ and IL-18 activation in human osteoarthritic cartilage. Osteoarthr Cartilage 8:186-196. https://doi.org/10.1053/joca.1999.0289

Mossadegh-Keller N, Sieweke MH (2018) Testicular macrophages: guardians of fertility. Cell Immunol 330:120-125. https://doi.org/ 10.1016/j.cellimm.2018.03.009

Mossadegh-Keller N, Gentek R, Gimenez G, Bigot S, Mailfert S, Sieweke MH (2017) Developmental origin and maintenance of distinct testicular macrophage populations. J Exp Med 214:28292841. https://doi.org/10.1084/jem.20170829

Nehar D, Mauduit C, Boussouar F, Benahmed M (1997) Tumor necrosis factor- $\alpha$-stimulated lactate production is linked to lactate dehydrogenase A expression and activity increase in porcine cultured Sertoli cells. Endocrinology 138:1964-1971. https://doi.org/ 10.1210/endo.138.5.5098

Nes WD, Lukyanenko YO, Jia ZH, Quideau S, Howald WN, Pratum TK, West RR, Hutson JC (2000) Identification of the lipophilic factor produced by macrophages that stimulates steroidogenesis. Endocrinology 141:953-958. https://doi.org/10.1210/endo.141.3. 7350

O'Bryan MK, Hedger MP (2008) Inflammatory networks in the control of spermatogenesis: chronic inflammation in an immunologically privileged tissue? Adv Exp Med Biol 636:92-114. https://doi.org/ 10.1007/978-0-387-09597-4_6

Ogilvie KM, Hales KH, Roberts ME, Hales DB, Rivier C (1999) The inhibitory effect of intracerebroventricularly injected interleukin 1 on testosterone secretion in the rat: role of steroidogenic acute regulatory protein 1. Biol Reprod 60:527-533. https://doi.org/10. 1095/biolreprod60.2.527

Pasin JSM, Ferreira APO, Saraiva ALL, Ratzlaff V, Andrighetto R, Tomazetti J, Ávila DS, Alves SH, Rubin MA, Ferreira J et al (2010) Diacerein decreases TNF- $\alpha$ and IL-1 $\beta$ levels in peritoneal fluid and prevents Baker's yeast-induced fever in young rats. Inflamm Res 59:189-196. https://doi.org/10.1007/ s00011-009-0085-8

Pavelka K, Bruyère $\mathrm{O}$, Cooper $\mathrm{C}$, Kanis JA, Leeb BF, Maheu E, Martel-Pelletier J, Monfort J, Pelletier JP, Rizzoli R et al (2016) Diacerein: benefits, risks and place in the management of osteoarthritis. an opinion-based report from the ESCEO. Drugs Aging 33:75-85. https://doi.org/10.1007/s40266-016-0347-4

Pentikäinen V, Pentikäinen P, Erkkilä K, Erkkilä E, Suomalainen L, Otala M, Pentikäinen MO, Parvinen M, Dunkel L (2001) TNF down-regulates the Fas Ligand and inhibits germ cell apoptosis in the human testis. J Clin Endocrinol Metab 86:4480-4488. https:// doi.org/10.1210/jcem.86.9.7861

Ramos-Zavala MG, González-Ortiz M, Martínez-Abundis E, RoblesCervantes JA, González-López R, Santiago-Hernández NJ (2011) Effect of diacerein on insulin secretion and metabolic control in drug-naive patients with type 2 diabetes: a randomized clinical trial. Diabetes Care 34:1591-1594. https://doi.org/10.2337/ dc11-0357

Sasso-Cerri E, Oliveira B, de Santi F, Beltrame FL, Caneguim BH, Cerri PS (2017) The antineoplastic busulphan impairs peritubular and Leydig cells, and vitamin B12 stimulates spermatogonia proliferation and prevents busulphan-induced germ cell death. Biomed Pharmacother 95:1619-1630. https://doi.org/10.1016/j. biopha.2017.08.131

Schlatt S, Rosiepen G, Weinbauer GF, Rolf C, Brook PF, Nieschlag E (1999) Germ cell transfer into rat, bovine, monkey and human testes. Hum Reprod 4:144-150. https://doi.org/10.1093/humrep/ 14.1.144

Shin MS, Kang Y, Wahl ER, Park HJ, Lazova R, Leng L, Mamula M, Krishnaswamy S, Bucala R, Kang I (2019) Macrophage migration inhibitory factor regulates U1 small nuclear RNP immune complex-mediated activation of the NLRP3 Inflammasome. Arthritis Rheumatol 71:109-120. https://doi.org/10.1002/art.40672

Shum WWC, Hill E, Brown D, Breton S (2013) Plasticity of basal cells during postnatal development in the rat epididymis. Reproduction 146:455-469. https://doi.org/10.1530/REP-12-0510

Smith LB, Walker WH (2014) The regulation of spermatogenesis by androgens. Semin Cell Dev Biol 3:02-13. https://doi.org/10. 1016/j.semcdb.2014.02.012

Smith LB, O'Shaughnessy PJ, Rebourcet D (2015) Cell-specific ablation in the testis: what have we learned? Andrology 3:1035-1049. https://doi.org/10.1111/andr.12107

Söder O, Sultana T, Jonsson C, Wahlgren A, Petersen C, Holst M (2000) The interleukin-1 system in the testis. Andrologia 32:52-55 
Suh JH, Gong EY, Hong CY, Park E, Ahn RS, Park KS, Lee K (2008) Reduced testicular steroidogenesis in tumor necrosis factor-alpha knockout mice. J Steroid Biochem Mol Biol 112:117-121. https:// doi.org/10.1016/j.jsbmb.2008.09.003

Suominen JS, Wang Y, Kaipia A, Toppari J (2004) Tumor necrosis factor-alpha (TNF- $\alpha$ ) promotes cell survival during spermatogenesis, and this effect can be blocked by infliximab, a TNF- $\alpha$ antagonist. Eur J Endocrinol 151:629-640. https://doi.org/10. 1530/eje.0.1510629

Svechnikov KV, Sultana T, Söder O (2001) Age-dependent stimulation of Leydig cell steroidogenesis by interleukin-1 isoforms. Mol Cell Endocrinol 182:193-201. https://doi.org/10.1016/s0303-7207(01) 00554-8

Svechnikov KV, Stocco DM, Söder O (2003) Interleukin-1 $\alpha$ stimulates steroidogenic acute regulatory protein expression via p38 MAP kinase in immature rat Leydig cells. J Mol Endocrinol 30:59-67. https://doi.org/10.1677/jme.0.0300059

Syed V, Stephan JP, Gerard N, Legrand A, Parvinen M, Bardin CW, Jégou B (1995) Residual bodies activate Sertoli cell interleukin-1 $\alpha(\mathrm{IL}-1 \alpha)$ release, which triggers IL- 6 production by an autocrine mechanism, through the lipoxygenase pathway. Endocrinology 136:3070-3078. https://doi.org/10.1210/endo.136.7.7789334

Tamura T, Ohmori K (2001) Rhein, an active metabolite of diacerein, suppresses the interleukin-1-induced proteoglycan degradation in cultured rabbit articular chondrocytes. Jpn J Pharmacol 85:101104. https://doi.org/10.1254/jjp.85.101

Tamura T, Shirai T, Kosaka N, Ohmori K, Takafumi N (2002) Pharmacological studies of diacerein in animal models of inflammation, arthritis and bone resorption. Jpn J Pharmacol 448:81-87. https:// doi.org/10.1016/s0014-2999(02)01898-8

Tremellen K, McPhee N, Pearce K, Benson S, Schedlowski M, Engler $\mathrm{H}$ (2018) Endotoxin-initiated inflammation reduces testosterone production in men of reproductive age. Am J Physiol Endocrinol
Metab 314:E206-E213. https://doi.org/10.1152/ajpendo.00279. 2017

Van Gorp H, Delputte PL, Nauwynck HJ (2010) Scavenger receptor CD163, a jack-of-all-trades and potential target for cell-directed therapy. Mol Immunol 47:1650-1660. https://doi.org/10.1016/j. molimm.2010.02.008

Verhoeven G, Cailleau J, Van Damme J, Billiau A (1988) Interleukin-1 stimulates steroidogenesis in cultured rat Leydig cells. Mol Cell Endocrinol 57:51-60. https://doi.org/10.1016/0303-7207(88) 90031-7

Voronov E, Dotan S, Krelin Y, Song X, Elkabets M, Carmi Y, Rider P, Cohen I, Romzova M, Kaplanov I, Apte RN (2013) Unique versus redundant functions of IL- $1 \alpha$ and IL- $1 \beta$ in the tumor microenvironment. Front Immunol 4:177. https://doi.org/10.3389/fimmu. 2013.00177

Wang D, Nagpal ML, Calkins JH, Chang W, Sigel MM, Lin T (1991) Interleukin-1 $\beta$ induces interleukin-l $\alpha$ messenger ribonucleic acid expression in primary cultures of Leydig cells. Endocrinology 129:2862-2866. https://doi.org/10.1210/endo-129-6-2862

Warren DW, Pasupuleti V, Lu Y, Platler BW, Horton R (1990) Tumor necrosis factor and interleukin-1 stimulate testosterone secretion in adult male rat Leydig cells in vitro. J Androl 11:353-360

Winnall WR, Hedger MP (2013) Phenotypic and functional heterogeneity of the testicular macrophage population: a new regulatory model. J Reprod Immunol 97:147-158. https://doi.org/10.1016/j. jri.2013.01.001

Publisher's Note Springer Nature remains neutral with regard to jurisdictional claims in published maps and institutional affiliations. 